\title{
Flavonoid Fraction of Orange and Bergamot Juices Protect Human Lung Epithelial Cells from Hydrogen Peroxide-Induced Oxidative Stress
}

\author{
Nadia Ferlazzo, ${ }^{1}$ Giuseppa Visalli, ${ }^{2}$ Antonella Smeriglio,, ${ }^{1}$ Santa Cirmi, ${ }^{1}$ \\ Giovanni Enrico Lombardo, ${ }^{1}$ Pietro Campiglia, ${ }^{3}$ Angela Di Pietro, ${ }^{2}$ and Michele Navarra ${ }^{1}$ \\ ${ }^{1}$ Department of Drug Sciences and Products for Health, University of Messina, Viale Annunziata, 98168 Messina, Italy \\ ${ }^{2}$ Department of Biomedical Sciences and Morphological and Functional Images, University of Messina, \\ Via Consolare Valeria, 98100 Messina, Italy \\ ${ }^{3}$ Department of Pharmaceutical and Biomedical Sciences, University of Salerno, Via Ponte don Melillo, Fisciano, 84084 Salerno, Italy
}

Correspondence should be addressed to Michele Navarra; mnavarra@unime.it

Received 7 April 2015; Revised 21 May 2015; Accepted 26 May 2015

Academic Editor: Siyaram Pandey

Copyright (C) 2015 Nadia Ferlazzo et al. This is an open access article distributed under the Creative Commons Attribution License, which permits unrestricted use, distribution, and reproduction in any medium, provided the original work is properly cited.

It has been reported that oxidant/antioxidant imbalance triggers cell damage that in turn causes a number of lung diseases. Flavonoids are known for their health benefits, and Citrus fruits juices are one of the main food sources of these secondary plant metabolites. The present study was designed to evaluate the effect of the flavonoid fraction of bergamot and orange juices, on $\mathrm{H}_{2} \mathrm{O}_{2}$-induced oxidative stress in human lung epithelial A549 cells. First we tested the antioxidant properties of both extracts in cell-free experimental models and then we assayed their capability to prevent the cytotoxic effects induced by $\mathrm{H}_{2} \mathrm{O}_{2}$. Our results demonstrated that both Citrus juice extracts reduce the generation of reactive oxygen species and membrane lipid peroxidation, improve mitochondrial functionality, and prevent DNA-oxidative damage in A549 cells incubated with $\mathrm{H}_{2} \mathrm{O}_{2}$. Our data indicate that the mix of flavonoids present in both bergamot and orange juices may be of use in preventing oxidative cell injury and pave the way for further research into a novel healthy approach to avoid lung disorders.

We wish to remember fondly our friend and colleague Dr. Tony Tomaino and dedicate to him the present study.

\section{Introduction}

The functional properties of the respiratory apparatus make it particularly susceptible to oxidative stress, coming mainly from inhaled prooxidant compounds present in airborne pollutants, working environments, and cigarette smoke [1]. These pollutants trigger the overproduction of free radicals, such as reactive oxygen species (ROS). This leads to oxidative damage often linked to the etiopathogenesis of several chronic lung disorders, including chronic obstructive pulmonary disease (COPD), asthma, and adult respiratory distress syndrome (ARDS) [2]. Chronic respiratory diseases have a widespread and rapidly growing public health impact (affecting hundreds of millions of people worldwide) and consequently have a high economic impact and social cost [3]. The complex interactions between environmental and genetic factors occurring in lung diseases cause the activation of proteolytic enzymes, lipoxygenase and cyclooxygenase which in turn produce large quantities of ROS leading to pulmonary inflammation that is responsible for the progressive (and only partially reversible) restriction of lung airflow $[4,5]$.

In recent years there has been an extraordinary increase in the number of studies on various phytochemicals due to their antioxidant properties that enable them to counteract ROS overproduction. Among these, flavonoids, a family of polyphenols found especially in fruits, vegetables, red wine, and tea, have been extensively studied [6,7]. Flavonoids are plant secondary metabolites commonly found in the fruits 
and vegetables regularly consumed by humans. Their antioxidant activity ameliorates many inflammatory diseases and has linked to the maintenance of good health $[8,9]$. Several mechanisms are involved in the beneficial effects exerted by flavonoids, including the free radicals scavenging [10], the transition metal ions chelation [11], the enhancement of glutathione content, and modulation of defense genes expression via the Nrf2/ARE pathway [10,12-14]. Citrus fruits and their juices are the main food sources of flavonoids and have been extensively studied as regards their anticancer, cardiovascular, and anti-inflammatory activity [15].

The health properties of Citrus sinensis (orange) have long been studied [16], while scientific interest in Citrus bergamia (bergamot) derivatives has gained ground only in recent years $[17,18]$. We have recently reported the anticancer properties of bergamot juice (BJ) in different in vitro [19] and in vivo models [20] and proposed the flavonoid fraction of BJ (BJe) to be responsible for this action [21]. We have also shown that low concentrations of BJe reduce the LPS-induced inflammatory response in THP-1 monocytes through SIRT1-mediated $\mathrm{NF}-\kappa \mathrm{B}$ inhibition [22] and exert an anti-inflammatory effect in vivo [23].

The drugs currently available have proved poorly effective in treating or preventing airway diseases. Therefore, novel preventive and therapeutic approaches that target primarily the causative mechanisms of these diseases are needed. On the basis that oxidative stress plays a key role in the pathogenesis and progression of lung disorders, the use of antioxidants should be given a higher profile. In this regard, several studies have shown a beneficial links between fruit and vegetables or natural antioxidant intake and lung diseases $[24,25]$. Indirect epidemiological evidence reports a positive correlation with lung function and a negative one between apple intake and asthma prevalence and incidence suggesting that flavonoids might protect against COPD $[26,27]$. These findings are consistent with other research reporting that fruit consumption is negatively correlated with incidence of chronic nonspecific lung disease, prevalence of COPD symptoms, and asthma, thus improving lung function [28, 29]. Although the antiallergic and anti-inflammatory properties of flavonoids might explain their beneficial effects observed in asthma [27, 30], their real clinical effectiveness has yet to be established.

The present study was designed to evaluate the effect of the flavonoid fraction of both bergamot and orange juices against oxidative stress in human lung epithelial A549 cells.

\section{Material and Methods}

2.1. Biochemicals and Reagents. All chemicals and reagents were obtained from Sigma-Aldrich (Milan, Italy) unless otherwise specified.

2.2. Orange and Bergamot Juice Extracts. The flavonoid fraction of both orange and bergamot juices (FFOJ and FFBJ, resp.) were provided by the company "Agrumaria Corleone" (Palermo, Italy). The fruits of Citrus bergamia Risso \& Poiteau (bergamot) came from crops located in the province of
Reggio Calabria (Italy), while those of Citrus sinensis var. Tarocco (orange) were from groves situated in Eastern Sicily (Italy). The extracts were centrifuged, transformed into a powder by spray drying, and then stored at $-20^{\circ} \mathrm{C}$. Finally, they were defrosted, diluted in culture medium, $\mathrm{pH}$ adjusted to 7.4 , and filtered immediately prior to use.

2.3. Chemical Characterization of the Juices Extracts. Qualitative and quantitative composition of FFBJ and FFOJ were determined using previously described protocol [21, 22]. Briefly, both FFBJ and FFOJ were solubilized in methanol to a concentration of $1 \mathrm{mg} / \mathrm{mL}^{-1}$, ultrasonicated and filtered through a $0.2 \mu \mathrm{m}$ nylon membrane (Millipore, Milan, Italy), and then injected into a UHPLC coupled online to an LCMSIT-TOF mass spectrometer (Shimadzu, Kyoto, Japan). Identification of flavonoids was carried out on the basis of diode array spectra, MS molecular ions, and MS/MS fragmentation patterns. Data obtained were compared with those available in scientific literature. Molecular formulae were calculated by the Formula Predictor software (Shimadzu).

\subsection{Evaluation of Antioxidant Capacity}

2.4.1. Folin-Ciocalteu Method. The total phenolic contents of FFBJ and FFOJ were determined by means of the FolinCiocalteu-assay, following Tomaino et al. [31]. Briefly, $50 \mu \mathrm{L}$ of methanol/water solutions of different sample concentrations was added to $450 \mu \mathrm{L}$ of deionized water, $500 \mu \mathrm{L}$ of FolinCiocalteu reagent, and $500 \mu \mathrm{L}$ of $10 \%$ sodium carbonate solution and incubated in the dark at room temperature for $1 \mathrm{~h}$, vortexing every $10 \mathrm{~min}$. Absorbance was recorded at $786 \mathrm{~nm}$ (Prixma UV-Vis Spectrophotometers) against a blank containing $50 \mu \mathrm{L}$ of the same solvent used to dissolve the extracts. Total phenol content is expressed in $\mathrm{mg}$ of gallic acid equivalents (GAE/g of dried extract).

2.4.2. Quenching of the Stable 2,2-Diphenylpicrylhydrazyl (DPPH) Radical. The DPPH assay was used to evaluate the radical scavenging activity of FFBJ and FFOJ. Following the procedure devised by Tomaino et al. [31], different concentrations (ranging from 0.1 to $1 \mathrm{mg} / \mathrm{mL}$ ) of methanol/water solution of each extract or vehicle alone $(37.5 \mu \mathrm{L})$ were added to $1.5 \mathrm{~mL}$ of DPPH methanolic solution $(25 \mathrm{mg} / \mathrm{L})$. Absorbance was measured at $517 \mathrm{~nm} 30$ min after starting the reaction. Free radical scavenging capacity of juice extracts is expressed in mg of Trolox equivalents (TE/g of dried extract).

2.4.3. Oxygen Radical Absorbance Capacity (ORAC) Assay. Antioxidant activity of FFBJ and FFOJ against $2,2^{\prime}$-azobis $(2-$ amidinopropane) dihydrochloride $(\mathrm{AAPH})$ peroxyl radicals was chemically examined using the ORAC method described by Dávalos et al. [32] with some modifications. Briefly, several concentrations of FFBJ or FFOJ $(20 \mu \mathrm{L})$ in $75 \mathrm{mM}$ phosphate buffer solution ( $\mathrm{pH} 7.4$ ) were mixed with $120 \mu \mathrm{L}$ of $417 \mathrm{nM}$ fluorescein solution and incubated at $37^{\circ} \mathrm{C}$ for $15 \mathrm{~min}$ to which $60 \mu \mathrm{L}$ of AAPH $(40 \mathrm{mM})$ was then added. Fluorescence was recorded spectrofluorometrically every $30 \mathrm{sec}$ for $90 \mathrm{~min}$ ( $\lambda_{\text {ex }} 485 ; \lambda_{\text {em }}$ 520; FLUOstar Omega, BMG Labtech), and 
the decrease in fluorescence was monitored. A blank, using phosphate buffer instead of sample, and calibration solutions of Trolox $(10-100 \mu \mathrm{M})$ were also included in each assay. The ORAC value was calculated using the area under the fluorescence decay curves and is expressed in $\mu$ moles of TE/g of dried extract.

2.4.4. Reducing Power. The reducing power of FFBJ and FFOJ was determined following the method described by Martorana et al. [33]. In brief, $0.2 \mathrm{~mL}$ of several concentrations of extracts was mixed with $0.5 \mathrm{~mL}$ of $0.2 \mathrm{M}$ sodium phosphate buffer $(\mathrm{pH} 6.6)$ and $0.5 \mathrm{~mL}$ of $1 \% \mathrm{~K}_{3} \mathrm{Fe}(\mathrm{CN})_{6}$ and then incubated in a water bath at $50^{\circ} \mathrm{C}$ for $20 \mathrm{~min}$. Subsequently, $0.5 \mathrm{~mL}$ of $10 \%$ TCA was added to the mixture which was centrifuged at $8300 \times \mathrm{g}$ for $10 \mathrm{~min}$. The supernatant $(0.5 \mathrm{~mL})$ was then mixed with $0.5 \mathrm{~mL}$ of distilled water and $0.1 \mathrm{~mL}$ of $0.1 \%$ ferric chloride solution and absorbance measured at $700 \mathrm{~nm}$. Increased absorbance of the reaction mixture indicated increased reducing power. Ascorbic acid was used as a reference. Phosphate buffer was used as blank solution. Reducing power is expressed in $\mathrm{mg}$ of ascorbic acid equivalent (AAE)/g of dried extract.

2.5. Cells Culture Conditions and Treatment. The biological experiments were performed using a basal epithelial cell line A549 derived from human lung carcinoma (ATCC, Rockville, MD, USA). Cells were grown in 6-well plates (approximately $3 \times 10^{5}$ cells/well) and cultured in RPMI medium with $2 \mathrm{mM}$ L-glutamine (Gibco Invitrogen, Milan, Italy), 10\% (v/v) foetal bovine serum (FBS), $100 \mathrm{IU} \mathrm{mL}^{-1}$ penicillin, and $100 \mathrm{~g} \mathrm{~mL}^{-1}$ streptomycin at $37^{\circ} \mathrm{C}$ in a humidified $5 \% \mathrm{CO}_{2}$ atmosphere. When $80-90 \%$ confluence was reached, monolayers were used for experiments by adding FFBJ and FFOJ to obtain a final concentration of 25 and $50 \mu \mathrm{g} \mathrm{mL}^{-1}$ in cell medium with $2 \% \mathrm{FBS}$. After $18 \mathrm{~h}$, the medium was removed, and cells were washed and exposed to $200 \mu \mathrm{M} \mathrm{H}_{2} \mathrm{O}_{2}$ in phosphate buffer saline (PBS) solution (pH 7.4) containing $10 \mathrm{mM}$ D-glucose for a further $2 \mathrm{~h}$.

For each set of experiments, a negative control (untreated cultures) and a stressor control $\left(\mathrm{H}_{2} \mathrm{O}_{2}\right.$ alone) were prepared by replacing the extracts with PBS.

2.6. Cytofluorimetric Analyses. Fluorescence-activated cell sorting (FACS) techniques were employed to determine the following parameters: intracellular ROS, lipid hydroperoxides, 8-oxo-7,8-dihydro-2' ${ }^{\prime}$-deoxyguanosine (8-oxo-dG), transmembrane mitochondrial potential $\left(\Delta \psi_{\mathrm{m}}\right)$, and cell viability. After each experiment, the cells were harvested, centrifuged at $1000 \times \mathrm{g}$ for $5 \mathrm{~min}$, and washed and suspended in PBS. Aliquots of cell suspensions $\left(\sim 2 \times 10^{5}\right.$ cells $\left.\mathrm{mL}^{-1}\right)$ were used for each probe as described below.

The lipophilic membrane-permeable 2-7-dichlorofluorescein diacetate (DCF-DA, $1 \mu \mathrm{M})$ was used as probe to evaluate intracellular ROS. The molecule, which undergoes deacetylation by intracellular esterases, is rapidly oxidized in its highly fluorescent derivative $2^{\prime}-7^{\prime}$-dichlorofluorescein (DCF) in the presence of ROS. The loaded cell suspensions were incubated at $37^{\circ} \mathrm{C}$ for $30 \mathrm{~min}$ and the fluorescent signals were collected in the FL-1 channel $(530 \pm 20 \mathrm{~nm})$ [34].

Lipid hydroperoxides were detected using the diphenyl-1pyrenylphosphine probe (DPPP; Invitrogen Molecular Probe, Milan, Italy) as previously reported [34]. The probe reacts stoichiometrically with lipid hydroperoxides in cell membranes to yield a fluorescent phosphine oxide $(\mathrm{DPPP}=\mathrm{O})$ and the corresponding hydroxide. DPPP was added to cell suspensions to obtain a final concentration of $150 \mu \mathrm{M}$ and incubated at $37^{\circ} \mathrm{C}$ for $3 \mathrm{~h}$. Fluorescent phosphine oxide signals were then collected in the FL-1 channel.

The fluorescent probe rhodamine 123 (R123; Invitrogen Molecular Probes) was used to assess the $\Delta \psi_{\mathrm{m}}$ due to its ability to cross the mitochondrial membrane and accumulate in the matrix of functional mitochondria. The fluorochrome R123 $(10 \mu \mathrm{M})$ was added to the cell suspensions and incubated at $37^{\circ} \mathrm{C}$ for $10 \mathrm{~min}$. Signals were collected in the fluorescence channel above $600 \mathrm{~nm}$ (FL-2 channel) [35].

Levels of 8-oxo-dG were measured using the FITClabelled avidin probe to assess oxidative DNA damage [21]. This technique is based on the high affinity of avidin to 8hydroxyguanine (8-OH-Gua) due to the remarkable structural similarities between the hydroxylated form $(8-\mathrm{OH}-$ Gua) and biotin. The probe binds with high specificity to 8oxo-dG and does not require sample pretreatment for DNA isolation and hydrolysis, thus reducing artifactual oxidation [36]. In detail, cells permeabilised with methanol (15 $\mathrm{min}$ at $\left.-20^{\circ} \mathrm{C}\right)$ were incubated with avidin-FITC conjugate $(0.2 \mu \mathrm{M})$ at $37^{\circ} \mathrm{C}$ for $1 \mathrm{~h}$, and then the fluorescence was collected in the FL-1 channel. The emission values detected in untreated cells correspond to $4.5 \pm 1.78$-oxo- $\mathrm{dG} / 10^{7} \mathrm{dG}$, which is the background level of oxidised base in A549 [37].

Cell viability was evaluated by adding propidium iodide $\left(3 \mu \mathrm{g} \mathrm{mL}{ }^{-1}\right)$ to cell suspensions at $4^{\circ} \mathrm{C}$ for $3 \mathrm{~min}$. Dead cells, stained with the DNA intercalating probe, were counted by measuring emission signals in the FL-3 channel.

The data collected from each probe were used to draw the respective curves by calculating the average of cell percentages for each emission value. In FACS analyses, the weighted average of emission values per 100 cells was calculated and is expressed in arbitrary fluorescence units (AFU). The values obtained were used to calculate the percentage changes $(\% \Delta)$ compared to the respective control.

2.7. Comet Assay. Cells treated as reported above were assayed for DNA integrity by the alkaline version of the comet assay following Picerno et al. [38]. Tests were performed in duplicate on about $2 \times 10^{4}$ cells per spot, and electrophoresis was carried out at $300 \mathrm{~mA}$ and $25 \mathrm{~V}\left(0.86 \mathrm{~V} \mathrm{~cm}^{-1}\right)$ for $30 \mathrm{~min}$. The slides, stained with ethidium bromide $\left(20 \mu \mathrm{g} \mathrm{mL}^{-1}\right)$, were analysed within $24 \mathrm{~h}$ at $400 \mathrm{x}$ magnification under a DMIRB fluorescence microscope (Leica Microsystem Heidelberg $\mathrm{GmbH}$, Mannheim, Germany), equipped with a digital camera (Canon, Milan, Italy).

One hundred randomly selected nuclei were acquired for each coded spot and underwent automated image analysis CASP. The following parameters were considered: tail length 
TABLE 1: Concentration of flavonoids identified in both FFBJ and FFOJ, expressed in $\mathrm{mg} / \mathrm{g}$ of dried extract.

\begin{tabular}{|c|c|c|c|}
\hline \multicolumn{2}{|c|}{ FFBJ } & \multicolumn{2}{|c|}{ FFOJ } \\
\hline Compound & $\mathrm{mg} / \mathrm{g}$ & Compound & $\mathrm{mg} / \mathrm{g}$ \\
\hline Vicenin-2 & $11.61 \pm 0.38$ & Vicenin-2 & $43.34 \pm 0.50$ \\
\hline Lucenin- $24^{\prime}$-methyl ether & $10.29 \pm 1.24$ & Lucenin-2 $4^{\prime}$-methyl ether & $22.20 \pm 1.10$ \\
\hline Eriocitrin & $8.89 \pm 0.49$ & Neohesperidin & $9.95 \pm 0.98$ \\
\hline Neoeriocitrin & $51.73 \pm 2.33$ & Eriocitrin & $2.20 \pm 0.70$ \\
\hline Poncirin & $18.41 \pm 0.20$ & Narirutin & $89.55 \pm 4.11$ \\
\hline Orientin $4^{\prime}$-methylether & $14.85 \pm 2.10$ & Neodiosmin & $1.18 \pm 2.14$ \\
\hline Naringin & $91.90 \pm 1.82$ & Hesperidin & $231.98 \pm 6.65$ \\
\hline Rhoifolin & $19.96 \pm 0.74$ & Didymin & $15.97 \pm 3.14$ \\
\hline Hesperidin & $7.49 \pm 0.31$ & Sinensetin & $3.28 \pm 0.49$ \\
\hline Isoquercitrin & $2.55 \pm 0.34$ & Tangeretin & $7.03 \pm 0.37$ \\
\hline Neohesperidin & $95.33 \pm 2.00$ & Nobiletin & $15.09 \pm 1.31$ \\
\hline Neodiosmin & $12.39 \pm 2.67$ & & \\
\hline Narirutin & $4.97 \pm 0.89$ & & \\
\hline Melitidin & $79.47 \pm 1.15$ & & \\
\hline Brutieridin & $14.73 \pm 1.38$ & & \\
\hline Naringenin & $41.48 \pm 0.20$ & & \\
\hline Hesperetin & $53.84 \pm 0.27$ & & \\
\hline Diosmetin & $12.36 \pm 2.09$ & & \\
\hline
\end{tabular}

(TL), percentage of DNA in the tail (TDNA\%), and tail moment (TM).

2.8. ROS and $\Delta \psi_{\mathrm{m}}$ Determinations by Confocal Microscopy Observations. A549 cells were grown on cell chamber slides and treated as described above. The two probes DCF-DA and R123 were used separately to load cells. Treated and untreated cells were observed using TCS-SP2 confocal laser scanning microscopy (CLSM) equipped with an $\mathrm{Ar} / \mathrm{Kr}$ laser (Leica Microsystems, Germany).

2.9. Statistical Analysis. All data are presented as mean \pm SEM based on at least three independent experiments. Significance was set at $P<0.05$. Comparisons and correlations were calculated using one-way analysis of variance (ANOVA) and Pearson's correlation coefficient, respectively.

\section{Results}

3.1. Chemical Composition of FFBJ and FFOJ. The chemical composition of the FFBJ and FFOJ extracts used in this study are shown in Table 1 and expressed in $\mathrm{mg} / \mathrm{g}$ of dried extract. Figure 1 shows the chemical structures of the flavonoids detected. As expected, neohesperidin, naringin, hesperetin, and melitidin were the main compounds present in FFBJ, although neoeriocitrin and naringenin were also present in quite large quantities. In FFOJ the highest amounts of flavonoids present were hesperidin, narirutin, and vicenin2. Although both extracts belong to the Citrus family, FFBJ and FFOJ differed regarding their abundance in flavonoids and the relative percentages (Table 1). For instance, some compounds present in FFBJ were not present or undetectable in FFOJ, while hesperidin and narirutin were abundant in
TABLE 2: Antioxidant activity of FFBJ and FFOJ evaluated by chemical tests. Results are reported as mean \pm SEM of three experiments performed in triplicate and expressed in standard equivalent/g of dried extract. Data were analyzed by Student's $t$-test for unpaired data. ${ }^{*} P<0.05,{ }^{* *} P<0.01$, and ${ }^{* * *} P<0.001$.

\begin{tabular}{lcc}
\hline & FFBJ & FFOJ \\
\hline $\begin{array}{l}\text { ORAC } \\
\mu \text { mol TE/g }\end{array}$ & $8054.17 \pm 606.11$ & $5166.05 \pm 205.68^{* *}$ \\
$\begin{array}{l}\mathrm{DPPH} \\
\mathrm{mg} \mathrm{TE} / \mathrm{g}\end{array}$ & $74.5 \pm 10.8$ & $68.3 \pm 4.05$ \\
$\begin{array}{l}\text { Folin-Ciocalteu } \\
\text { mg GAE/g }\end{array}$ & $129.17 \pm 2$ & $122.8 \pm 3.3^{*}$ \\
$\begin{array}{l}\text { Reducing power } \\
\text { mg AAE/g }\end{array}$ & $99.05 \pm 2$ & $62.6 \pm 3.1^{* * *}$ \\
\hline
\end{tabular}

FFOJ and scarce in FFBJ. A slight difference in chemical composition may reflect significant differences in both physicochemical properties and biological activities.

3.2. Antioxidant Capacity in Cell-Free Models. The antioxidant and radical scavenging properties of FFBJ and FFOJ were determined using a range of tests that highlighted significant differences between the two Citrus juice extracts. As shown in Table 2, total phenolic compounds content, measured by the Folin-Ciocalteu method, was higher in FFBJ than in FFOJ $(P<0.05)$. This was directly correlated to the overall reducing capacity of a sample measured by the Reducing Power test. The latter assay confirmed a significant difference between FFBJ and FFOJ $(P<0.001)$. Moreover, antioxidant capacity, evaluated by ORAC assay, confirmed the significant differences between the two extracts $(P<0.01)$, 

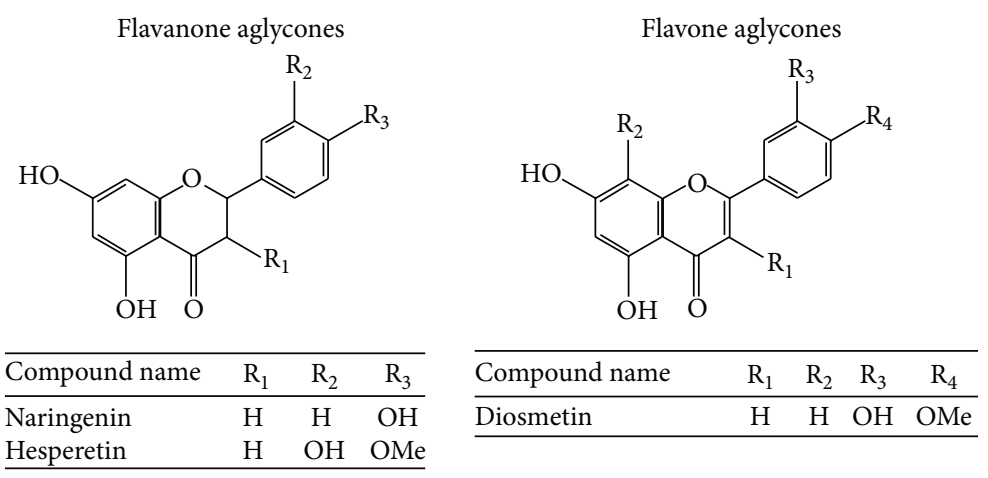

Flavone-C-glucosides and flavone-O-glycosides<smiles>[R]c1ccc(-c2oc3c([R])c(Br)c([R])c(O)c3c(=O)c2Br)cc1Br</smiles>

\begin{tabular}{lcccccc}
\hline Compound name & $\mathrm{R}_{1}$ & $\mathrm{R}_{2}$ & $\mathrm{R}_{3}$ & $\mathrm{R}_{4}$ & $\mathrm{R}_{5}$ & $\mathrm{R}_{6}$ \\
\hline Vicenin-2 & $\mathrm{H}$ & $\mathrm{Glu}$ & $\mathrm{OH}$ & $\mathrm{Glu}$ & $\mathrm{H}$ & $\mathrm{OH}$ \\
Lucenin-2 4'-methyl ether & $\mathrm{H}$ & $\mathrm{Glu}$ & $\mathrm{OH}$ & $\mathrm{Glu}$ & $\mathrm{OH}$ & $\mathrm{OMe}$ \\
Orientin 4' methyl ether & $\mathrm{H}$ & $\mathrm{H}$ & $\mathrm{OH}$ & $\mathrm{Glu}$ & $\mathrm{OH}$ & $\mathrm{OMe}$ \\
Rhoifolin & $\mathrm{H}$ & $\mathrm{H}$ & $\mathrm{O}^{\prime} \mathrm{Nh}^{\mathrm{b}}$ & $\mathrm{H}$ & $\mathrm{OH}$ & $\mathrm{OH}$ \\
Neodiosmin & $\mathrm{H}$ & $\mathrm{H}$ & $\mathrm{O}^{\mathrm{N} h}$ & $\mathrm{H}$ & $\mathrm{OH}$ & $\mathrm{OMe}$ \\
Isoquercitrin & $\mathrm{O}-\mathrm{Ru}^{\mathrm{a}}$ & $\mathrm{H}$ & $\mathrm{OH}$ & $\mathrm{H}$ & $\mathrm{OH}$ & $\mathrm{OH}$ \\
\hline
\end{tabular}

FIGURE 1: Chemical structures of flavonoids found in FFBJ and FFOJ. ${ }^{a}$ Rutinose (Ru). ${ }^{b}$ Neohesperidose (Nh). Methyl group (Me). Glucoside (Glu).

while no statistically significant differences were detected by the $\mathrm{DPPH}^{\bullet}$ test.

3.3. Biological Assessment. To study the potential protective effects of both FFBJ and FFOJ in different compartments of oxidatively injured A549 lung epithelial cells, we first measured the intracellular content of ROS and checked cell viability in $\mathrm{H}_{2} \mathrm{O}_{2}$-stressed or unstressed cells, which had either been pretreated or not with Citrus extracts. As expected, DCF emission values in cells treated with FFBJ and FFOJ for $18 \mathrm{~h}$ did not differ significantly from the background values recorded in untreated cells (Figure 2). Similarly, no differences between FFBJ- or FFOJ-treated and untreated cells were recorded in PI emission values (Figure 3 ). These results indicate that the extracts at both 25 and $50 \mu \mathrm{g} / \mathrm{mL}$ concentrations did not trigger ROS generation or affect cell viability (always $>90 \%$ ). Instead, DCF emission values in $\mathrm{H}_{2} \mathrm{O}_{2}$-stressed cells were up to 6.7-fold higher than those

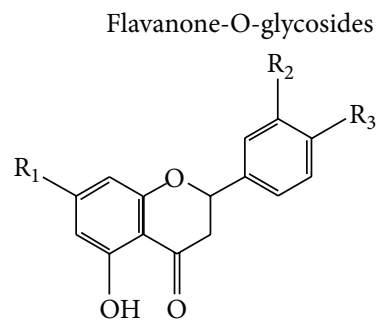

\begin{tabular}{|c|c|c|c|}
\hline Compound name & $\mathrm{R}_{1}$ & $\mathrm{R}_{2}$ & $\mathrm{R}_{3}$ \\
\hline Eriocitrin & $\mathrm{O}-\mathrm{Ru}^{\mathrm{a}}$ & $\mathrm{OH}$ & $\mathrm{OH}$ \\
\hline Neoeriocitrin & $\mathrm{O}-\mathrm{Nh}^{\mathrm{b}}$ & $\mathrm{OH}$ & $\mathrm{OH}$ \\
\hline Poncirin & $\mathrm{O}-\mathrm{Nh}^{\mathrm{b}}$ & $\mathrm{H}$ & $\mathrm{OMe}$ \\
\hline Naringin & $\mathrm{O}-\mathrm{Nh}^{\mathrm{b}}$ & $\mathrm{H}$ & $\mathrm{OH}$ \\
\hline Hesperidin & $\mathrm{O}-\mathrm{Ru}^{\mathrm{a}}$ & $\mathrm{OH}$ & $\mathrm{OMe}$ \\
\hline Neohesperidin & $\mathrm{O}-\mathrm{Nh}^{\mathrm{b}}$ & $\mathrm{OH}$ & $\mathrm{OMe}$ \\
\hline Narirutin & $\mathrm{O}-\mathrm{Ru}^{\mathrm{a}}$ & $\mathrm{H}$ & $\mathrm{OH}$ \\
\hline Melitidin & $\mathrm{O}-\mathrm{Nh}^{\mathrm{b}}$ & $\mathrm{H}$ & $\mathrm{OH}$ \\
\hline Brutieridin & $\mathrm{O}-\mathrm{Nh}^{\mathrm{b}}$ & $\mathrm{OH}$ & $\mathrm{OMe}$ \\
\hline Didymin & $\mathrm{O}-\mathrm{Ru}^{\mathrm{a}}$ & $\mathrm{H}$ & $\mathrm{OMe}$ \\
\hline
\end{tabular}

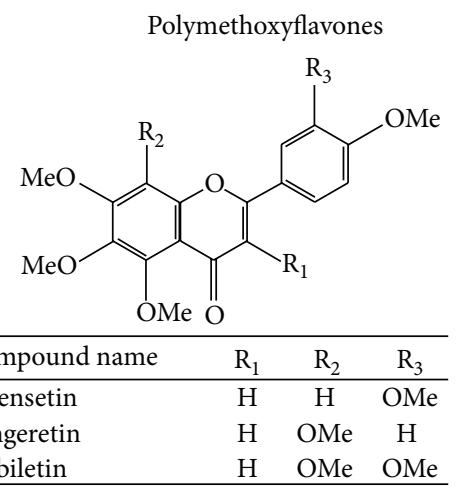




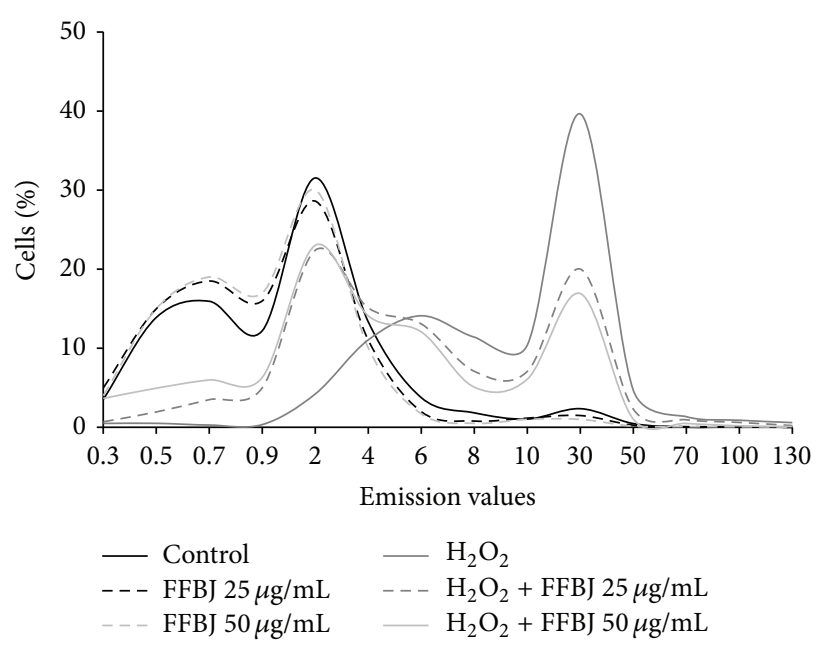

(a)

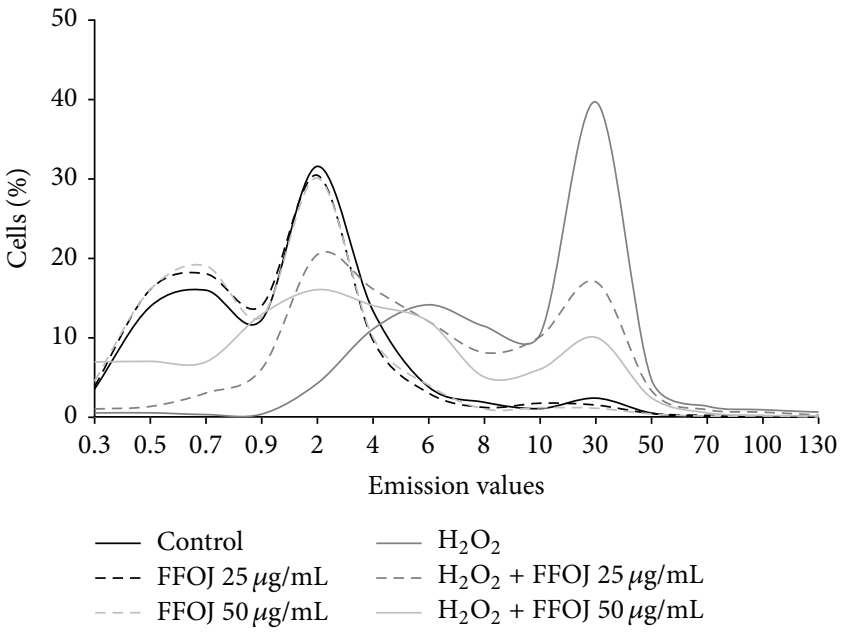

(b)

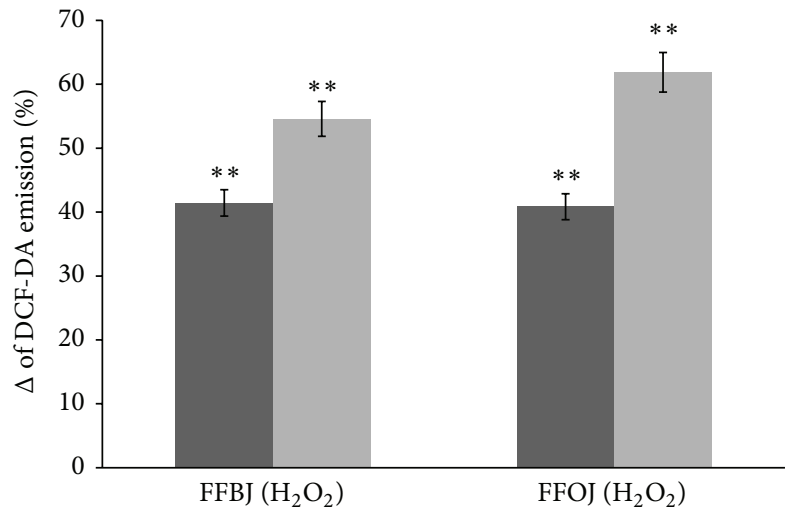

$25 \mu \mathrm{g} / \mathrm{mL}$

$50 \mu \mathrm{g} / \mathrm{mL}$

(c)

FIGURE 2: Cytofluorimetric evaluation of intracellular ROS. A549 cells treated for $18 \mathrm{~h}$ with FFBJ or FFOJ were oxidatively stressed by $\mathrm{H}_{2} \mathrm{O}_{2}$ $200 \mu \mathrm{M}$ for additional $2 \mathrm{~h}$. Results from FFBJ (a) or FFOJ (b) treatments. The curves shifted rightward to higher emission values indicate the increase of ROS production. Data from (a) and (b) are expressed as percentage of reduction (\% $\%$ ) of DCF-DA emission values in FFBJ or FFOJ-pretreated cells and then exposed to $\mathrm{H}_{2} \mathrm{O}_{2}$ compared to $\mathrm{H}_{2} \mathrm{O}_{2}$-stressed cells (c). The experiments were repeated at least three times. ${ }^{* *} P<0.01$ versus $\mathrm{H}_{2} \mathrm{O}_{2}$-treated cells.

then incubated with $\mathrm{H}_{2} \mathrm{O}_{2}$ in comparison to the cells exposed to $\mathrm{H}_{2} \mathrm{O}_{2}$ alone. The histograms illustrate that both extracts significantly reduced ROS production caused by $\mathrm{H}_{2} \mathrm{O}_{2}$ in A549 cells $(P<0.01)$.

The data from FACS analyses were confirmed by CLSM observations. Figure 4 shows that, in comparison to oxidatively stressed A549 cells, the presence of Citrus extracts dampened the fluorescence emission proportionally to the concentration employed.

The high lipid content of cell membranes makes them particularly susceptible to oxidative damage. We therefore measured the lipid hydroperoxides to investigate the consequences of the oxidative damage caused by $\mathrm{H}_{2} \mathrm{O}_{2}$ on the membrane lipids and also to examine the effect of our extracts. The level of lipid peroxidation in A549 cells increased up to 6 -fold after $2 \mathrm{~h}$ incubation with $200 \mu \mathrm{M}$ of
$\mathrm{H}_{2} \mathrm{O}_{2}$, an effect counteracted by preincubation with either extract (Figure 5). Interestingly, the DPPP emission value detected in $\mathrm{H}_{2} \mathrm{O}_{2}$-stressed cells were lowered by up to 40 and $55 \%$ by pretreatment with FFBJ at concentrations of 25 and $50 \mu \mathrm{g} / \mathrm{mL}$, respectively $(P<0.01)$. Similar results were obtained using FFOJ (45 and 60\% emission DPPP reduction by 25 and $50 \mu \mathrm{g} / \mathrm{mL}$ concentrations, resp.; $P<0.01$ ).

The strong correlation between redox imbalance and lipid hydroperoxides in $\mathrm{H}_{2} \mathrm{O}_{2}$-stressed cells $(r=0.96 ; P<0.001)$ strengthens the evidence supporting the potential of both extracts to counteract lipid peroxidation (Figure 6).

Since mitochondrial membrane phospholipids are key targets for lipid peroxidation involving highly polyunsaturated side chains, we further evaluated the ability of both extracts to restrain mitochondrial impairment. Figure 7 shows that incubation of A549 cells with $\mathrm{H}_{2} \mathrm{O}_{2}$ caused a drop 


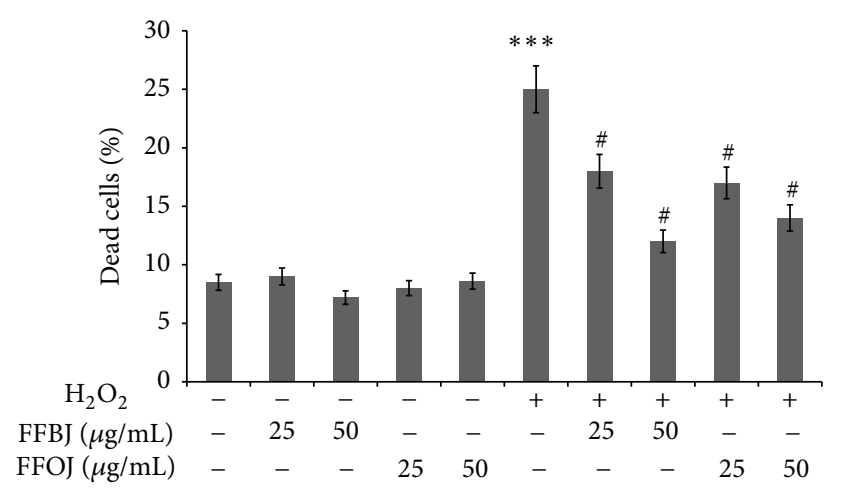

Figure 3: Effect of FFBJ or FFOJ on cell death induced by $\mathrm{H}_{2} \mathrm{O}_{2}$. The cells were treated for $18 \mathrm{~h}$ with FFBJ or FFOJ followed by incubation with $200 \mu \mathrm{M} \mathrm{H}_{2} \mathrm{O}_{2}$ for additional $2 \mathrm{~h}$. PI-positive cells were determined by flow cytometry collecting the emission signal in the FL- 3 channel. Data represent means \pm SEM of three separate experiments. ${ }^{* * *} P<0.001$ versus control cells and ${ }^{\#} P<0.05$ versus $\mathrm{H}_{2} \mathrm{O}_{2}$-treated cells.

in $\Delta \psi_{\mathrm{m}}$, as indicated by the peak of the R123 probe fluorescence emission on the left of the graph (Figures 7(a) and 7(b)). The presence of FFBJ or FFOJ lessened the ROS-induced mitochondrial impairment observed in stressed cells, reducing the number of cells with lower R123 fluorescence emission values. This is clearly shown in Figure 7(c) which presents the increases in weighted-averages fluorescence found in cultures preincubated with the Citrus extracts prior to $\mathrm{H}_{2} \mathrm{O}_{2}$ incubation, in comparison to the non-pretreated oxidatively stressed cells, set at $0(P<0.05$ and $P<0.01$ for 25 and $50 \mu \mathrm{g} / \mathrm{mL}$ of both extracts, resp.).

The CLSM observations confirmed the results from FACS analyses (Figure 8), showing that the presence of FFBJ or FFOJ reduced the fall in $\Delta \psi_{\mathrm{m}}$, as revealed by the increased emitted fluorescence.

Levels of 8-oxo-dG and DNA strand breaks were measured to study the effectiveness of the Citrus extracts to restrain DNA-oxidative damage. The results of cytofluorimetric analysis using a FITC-labelled avidin probe are reported in Figure 9. This shows that $18 \mathrm{~h}$ of treatment with FFBJ or FFOJ did not induce DNA oxidation since the emission values roughly overlapped those recorded in control cells. Despite the massive DNA damage induced by $2 \mathrm{~h}$ of $\mathrm{H}_{2} \mathrm{O}_{2} 200 \mu \mathrm{M}$ incubation, the pretreatment with FFBJ or FFOJ significantly decreased oxidative DNA damage by about 1.5 fold $(P<0.01$; Figure 9(a)). Similar results were obtained using the comet assay (Figure 9(b)).

\section{Discussion}

The pathogenic role of oxidative damage in chronicdegenerative diseases has escalated scientific interest in the potential use of different natural drugs for prevention and/or as adjuvant therapy. In this study we investigated the effects of flavonoids extracted from orange and bergamot juices on $\mathrm{H}_{2} \mathrm{O}_{2}$-induced oxidative stress in human alveolar type II epithelial A549 cells, which resemble the pathophysiological lung conditions of respiratory epithelium [39]. A549 cells have been extensively used to gain insight into the cellular and molecular mechanisms of pulmonary diseases because they retain the characteristics of alveolar cells [40]. Alveolar cells have the capacity to modify the inflammatory reaction within the alveolar space. In particular, type II alveolar epithelial cells control the volume and composition of the epithelial lining fluid, and, in the event of injury, they differentiate into type I alveolar epithelial cells to maintain the integrity of the alveolar wall.

Hydrogen peroxide, widely used in in vitro models of oxidative stress, is a physiological constituent of living cells and is continuously produced via diverse cellular pathways. Its intracellular steady-state concentration is controlled by various enzymatic and nonenzymatic antioxidant systems and is assumed to vary between 1 and $700 \mathrm{nM}$ [41]. Although $\mathrm{H}_{2} \mathrm{O}_{2}$ at physiological concentrations acts as a signaling molecule by modulating the expression of defense genes, levels above $1 \mu \mathrm{M}$ cause redox imbalance, inducing growth arrest and cell death [42]. Moreover, in Fenton-like reactions, $\mathrm{H}_{2} \mathrm{O}_{2}$ contributes to the formation of the hydroxyl radical $(\mathrm{OH})$ in the presence of free redox-active transition metals, amplifying cellular damage. Due to its high reactivity and very short half life (in aqueous solution less than $1 \mathrm{~ns}$ ), ${ }^{\circ} \mathrm{OH}$ is able to attack DNA, lipids, and proteins, more efficiently than other ROS.

The results of the present study suggest that, despite their qualitative and quantitative differences in the phenolic compounds content of FFBJ and FFOJ, both exert a significant and similar antioxidant effect on $\mathrm{H}_{2} \mathrm{O}_{2}$ cell injury. Indeed, although both bergamot and orange belong to the Citrus family, the characteristic flavonoid profile of their juices can influence their antioxidant properties. Significant differences were found between FFBJ and FFOJ, with higher activity observed for FFBJ extract than for FFOJ in a number of abiotic in vitro tests, including the ORAC, the FolinCiocalteu, and the Reducing Power assays. The latter two tests were carried out in alkaline and acid conditions, respectively. We used both tests to evaluate the antioxidant potential of polyphenolic compounds because an acidic $\mathrm{pH}$ may reduce in vitro phenolic antioxidant activity as a result of protonation, whereas an alkaline $\mathrm{pH}$ could enhance this activity [43]. Overall, with the exception of the DPPH test, all the cellfree assays provide evidence of a higher antioxidant activity of FFBJ compared to FFOJ.

Biological experiments were performed on A549 cells stressed by $\mathrm{H}_{2} \mathrm{O}_{2}$ injury. In this in vitro model, FFBJ behaved similarly to FFOJ, demonstrating an analogous antioxidant efficacy of both extracts. This observation, however, is quite in contrast to the results of tests performed in the cell-free models. We demonstrated that FFBJ and FFOJ were not only able to reduce ROS production, lipid hydroperoxides, and DNA damage induced by $\mathrm{H}_{2} \mathrm{O}_{2}$ in A549 cells, but also able to increase $\Delta \psi_{\mathrm{m}}$.

Several studies have examined the antioxidant activity of flavonoids by cell-free tests alone, further supporting the structure-functional relationship [44-46]. Very recently, Lago et al. reviewed the effects of different flavonoids in certain lung disease and the structure-activity relationships, 


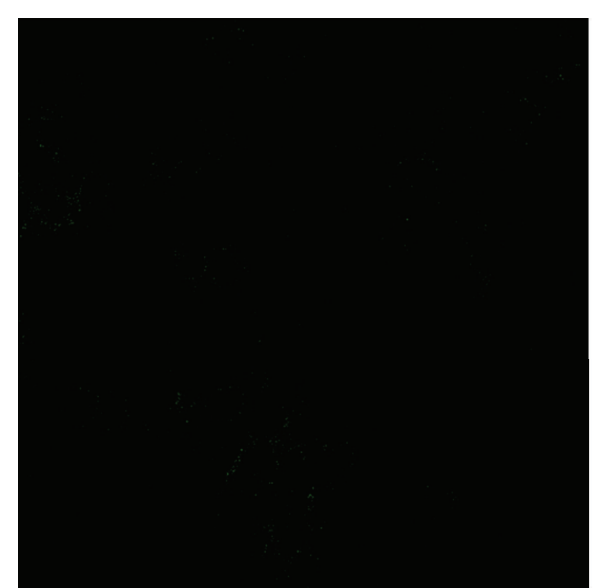

Control

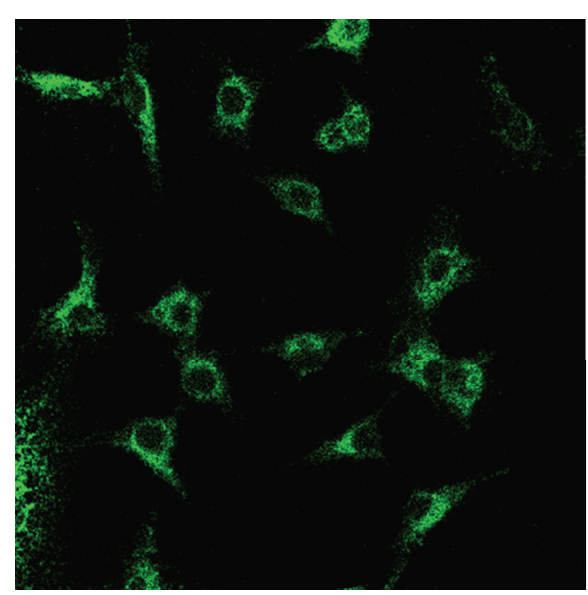

$\mathrm{H}_{2} \mathrm{O}_{2}+\mathrm{FFBJ} 25 \mu \mathrm{g} / \mathrm{mL}$

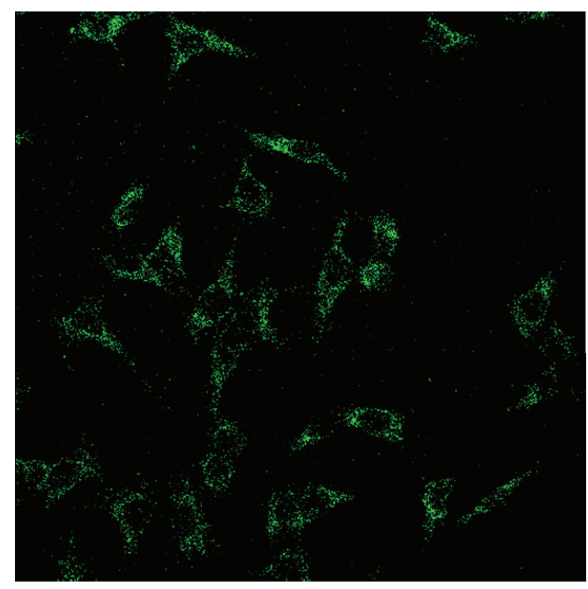

$\mathrm{H}_{2} \mathrm{O}_{2}+$ FFOJ $25 \mu \mathrm{g} / \mathrm{mL}$

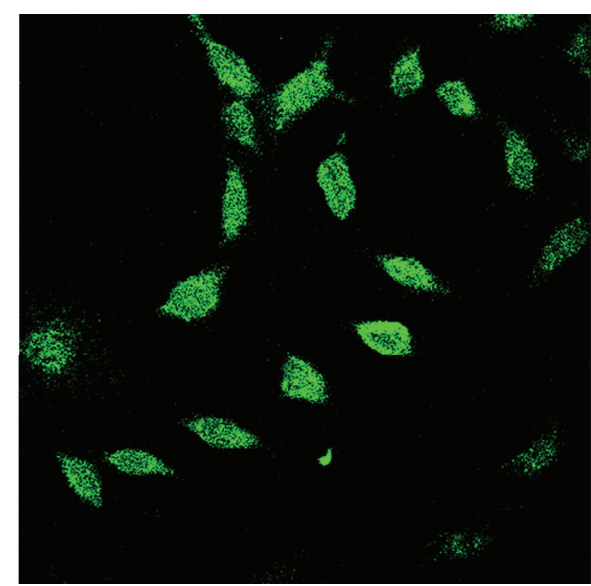

$\mathrm{H}_{2} \mathrm{O}_{2}$

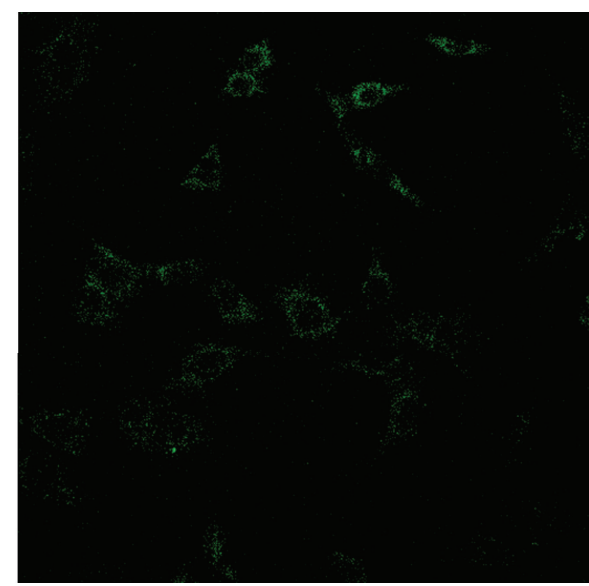

$\mathrm{H}_{2} \mathrm{O}_{2}+\mathrm{FFBJ} 50 \mu \mathrm{g} / \mathrm{mL}$

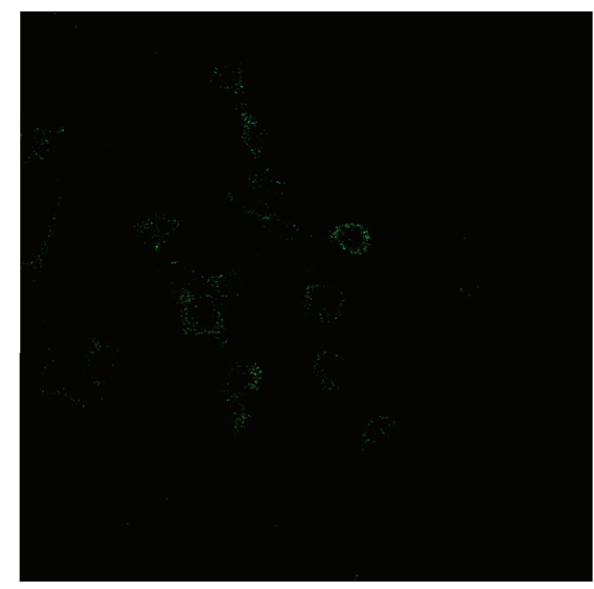

$\mathrm{H}_{2} \mathrm{O}_{2}+\mathrm{FFOJ} 50 \mu \mathrm{g} / \mathrm{mL}$

FIGURE 4: Confocal laser scanning microscope images of DCF-DA-stained cells. A549 cells grown on cell slides were preincubated with FFBJ or FFOJ and after $18 \mathrm{~h}$ exposed to $\mathrm{H}_{2} \mathrm{O}_{2} 200 \mu \mathrm{M}$. Green fluorescence represented the amounts of ROS. Images shown are representative of three independent experiments. 400x magnification.

linking the biological potential and the chemical profile of these compounds [47]. Moreover, there are a range of studies that have assayed the antioxidant properties of natural drugs or single molecules in abiotic, in vitro, or in vivo models $[48,49]$. However, few studies have been done which concomitantly analyse the antioxidant ability of two or more natural drugs both in cell-free and in cell-based assays [50-52]. The slight discrepancy between the results from chemical and biological assays found in this study could be due merely to the different experimental models employed. 


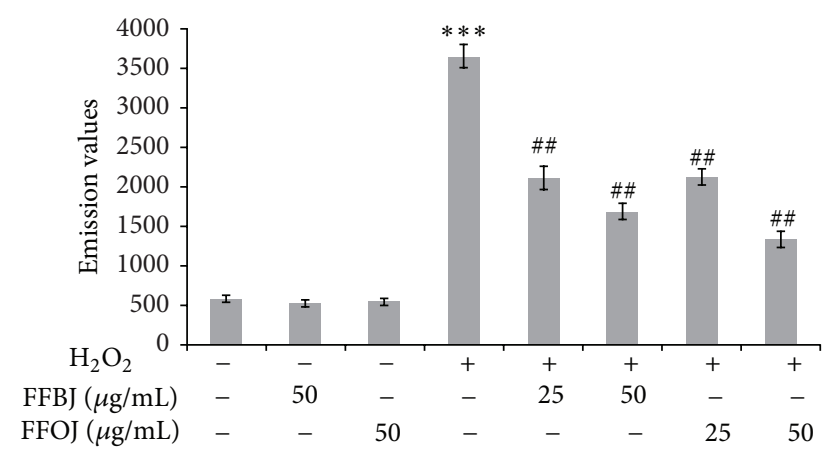

FIgURe 5: Cytofluorimetric evaluation of lipid hydroperoxides. The A549 cells incubated for $18 \mathrm{~h}$ with FFBJ or FFOJ were oxidatively stressed with $\mathrm{H}_{2} \mathrm{O}_{2} 200 \mu \mathrm{M}$ for $2 \mathrm{~h}$ and then loaded by DPPP probe. The graph reports the mean of fluorescence expressed in arbitrary fluorescence units (AFU) of three independent experiments. Data represent the mean \pm SEM of at least three separate experiments. ${ }^{* * * *} P<0.001$ versus control cells and ${ }^{\# \#} P<0.01$ versus $\mathrm{H}_{2} \mathrm{O}_{2}$-treated cells.

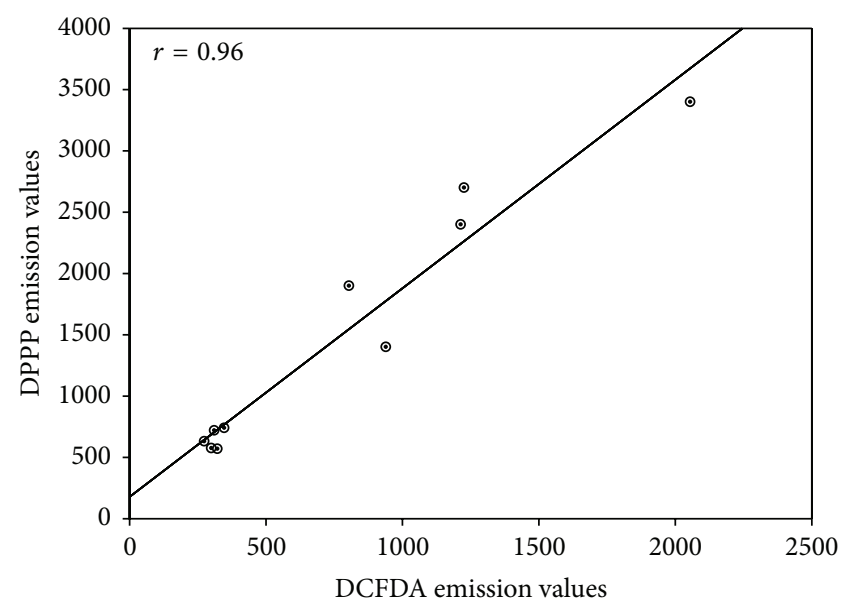

Figure 6: Pearson's correlation. Plot of DCF-DA versus DPPP emission values in A549 cells pretreated or not with FFBJ or FFOJ for $18 \mathrm{~h}$ and then incubated with $\mathrm{H}_{2} \mathrm{O}_{2} 200 \mu \mathrm{M}$ for additional $2 \mathrm{~h}$. $r=0.96 ; P<0.001$.

Indeed, while the chemical-based tests were performed under tightly controlled and, often, nonphysiological conditions, the biological ones were carried out in a more complex system (the cellular environment) and this may have influenced the experimental results. Moreover, antioxidant action is not limited to scavenging free radicals but includes the modulation of redox cell signaling and gene expression that greatly contribute to cellular antioxidant capacity. In addition, metabolic modifications occurring in cultured cells may substantially influence the antioxidant activity of flavonoids. In this regard, it should be stressed that A549 cells possess phases I and II enzymes capable of metabolizing xenobiotics $[39,53]$, which may help to explain the overlap in the antioxidant activity of FFBJ and FFOJ found in the cellbased assays in contrast to the more active performance of FFBJ than of FFOJ found in the cell-free models. It is therefore not surprising that differences emerged between the results from the chemical and biological tests, reported herein. Therefore, extreme caution is advised in extrapolating the performance of antioxidants from a cell-free assay to biological situations, and it is prudent to use more than a single method to evaluate the antioxidant properties of natural products. Our observations are consistent with the more recent literature, which supports the better predictive capacity of biological assays compared to chemical ones in order to evaluate the potential antioxidant activity of a compound or extract [52]. Chemical-based methods are useful for screening, because they are quick, easy to do, and cheap and have high-throughput and generally yield an index value that allows different products to be readily compared and ranked, while the cell-based assay are more appropriate to study the behaviour of an antioxidant under physiological conditions [50]. However, studies on animal models and human are necessary to assess the effectiveness of natural compounds. Indeed, it has been reported that flavonoids are extensively metabolised in vivo (especially when given orally) resulting in a significant alteration in their redox potentials.

Oxidative stress is the main pathological mechanism in lung disease and is directly linked to oxidation of proteins, DNA and lipids, mitochondrial impairment, and compromised lung defense mechanisms. $\mathrm{H}_{2} \mathrm{O}_{2}$ is an important marker of oxidative stress that can be generated by the xanthine/xanthine oxidase reaction, with higher amounts found in cell-free bronchoalveolar lavage fluid and plasma taken from both asthma and COPD patients, suggesting a central role in their pathogenesis [2]. This observation is strengthened by the evidence that patients with lung diseases are characterized by high concentrations of exhaled hydrogen peroxide, which further increases as the disease exacerbates [2]. Moreover, lipid peroxidation byproducts, including 8isoprostane and hydrocarbons, (e.g., ethane and pentane) are also detectable in the air exhaled by these patients [54, 55], suggesting that membrane lipid peroxidation represents a further key event implicated in lung disorders. The results of our study demonstrated that both FFBJ and FFOJ counteract ROS generation induced by $\mathrm{H}_{2} \mathrm{O}_{2}$ in A549 cells and prevent lipidic hydroperoxides generation, which are precursors of malondialdehyde (MDA) and 4-hydroxynonenal (4-HNE), these being end-products of lipid peroxidation capable of inactivating antioxidant enzymes and causing redox imbalance. In addition, MDA may form adducts with DNA bases, while 4-HNE produces exocyclic etheno-DNA-base adducts [56].

The main effect of lipid peroxidation is the dysfunction of mitochondrial membranes determining energy failure and a number of intracellular events leading to cell death. In a recent study we demonstrated that exposure of A549 cells to airborne metals causes mitochondrial impairment due to lipid peroxidation of polyunsaturated fatty acids in membrane phospholipids amplifying oxidative stress [35]. It is known that the phospholipids of the inner mitochondrial membrane play a key role in optimizing the activity of mitochondrial proteins including several anion carriers, ADP/ATP translocators and some electron transport complexes. Due to the double bonds of 


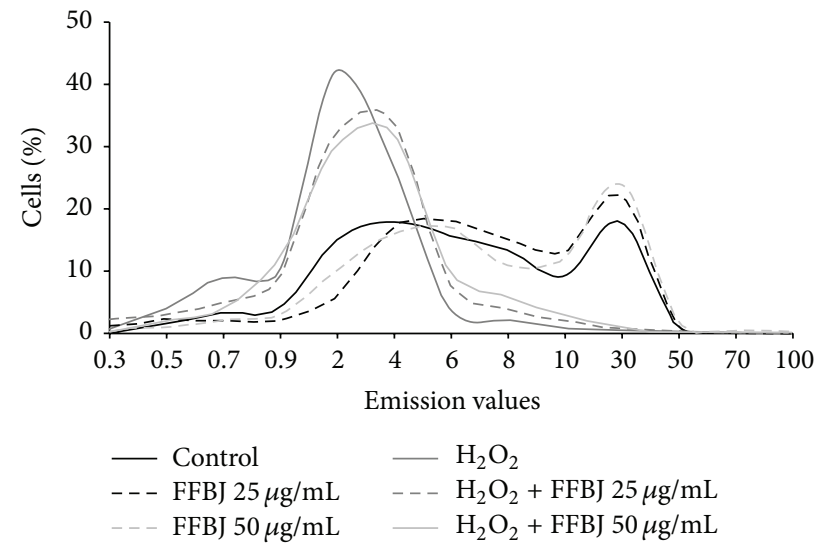

(a)

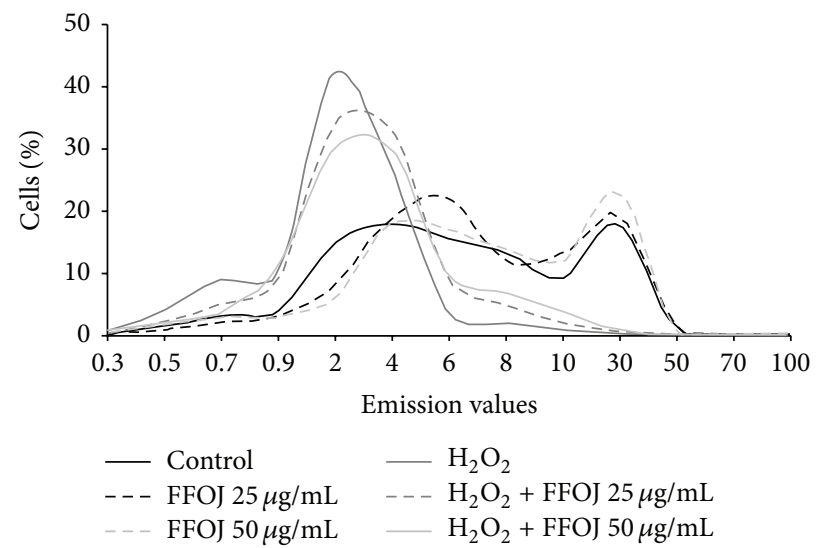

(b)

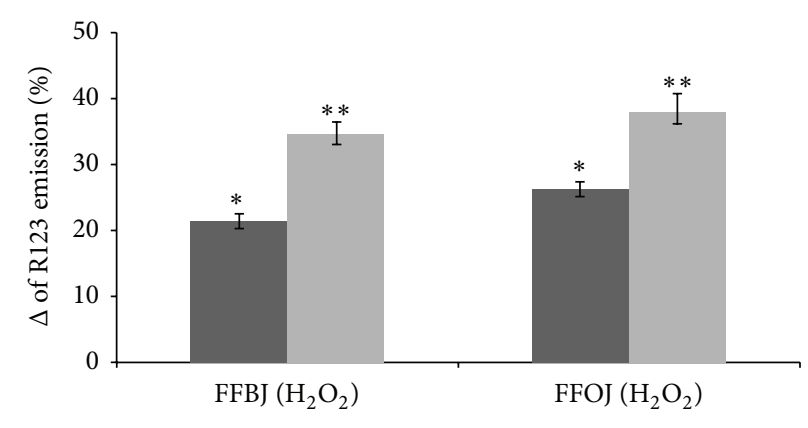

$25 \mu \mathrm{g} / \mathrm{mL}$

$50 \mu \mathrm{g} / \mathrm{mL}$

(c)

FIGURE 7: Effect of FFBJ or FFOJ on mitochondrial membrane potential in $\mathrm{H}_{2} \mathrm{O}_{2}$-treated cells. The cells treated with FFBJ or FFOJ and then exposed to $200 \mu \mathrm{M} \mathrm{H}_{2} \mathrm{O}_{2}$ for $2 \mathrm{~h}$ were loaded with R123 probe. Fluorescence was followed by flow cytometry. The shift of the curves to the left of the graph indicates the reduction of $\Delta \psi_{\mathrm{m}}$. Results from FFBJ (a) or FFOJ (b) exposure. In (c) are reported data from (a) and (b) expressed as percentage of increase $(\% \Delta)$ of R123 emission values in FFBJ- or FFOJ-pretreated cells subsequently exposed to $\mathrm{H}_{2} \mathrm{O}_{2}$ compared to $\mathrm{H}_{2} \mathrm{O}_{2}$-stressed cells. ${ }^{*} \mathrm{P}<0.05$ and ${ }^{* *} \mathrm{P}<0.01$ versus $\mathrm{H}_{2} \mathrm{O}_{2}$-treated cells.

their fatty acid constituents, mitochondrial phospholipids are particularly susceptible to peroxidative attack producing organelle impairment. Moreover, given that modified electron transport complexes cause a further increase of redox imbalance by endogenous ROS overproduction, a vicious circle is triggered, amplifying the oxidative cellular damage [57, 58]. Interestingly, the Citrus extracts used in this study reduced the drop in $\Delta \psi_{\mathrm{m}}$ induced by $\mathrm{H}_{2} \mathrm{O}_{2}$ in $\mathrm{A} 549$ cells, thus restoring mitochondrial functions.

\section{Conclusions}

Our study demonstrates that the antioxidant properties of the flavonoid mixtures present in both FFBJ and FFOJ are able to inhibit the prooxidant effects of $\mathrm{H}_{2} \mathrm{O}_{2}$ on lung epithelial cells. These findings support the role of bergamot and orange flavonoids in the treatment of oxidative stress-related disorders and pave the way toward novel therapeutic approaches to protect against oxidative injury in lung diseases, a goal potentially achievable after evaluating the effectiveness of these extracts in vivo.

\section{Abbreviations}

AAE: Ascorbic acid equivalent

AFU: Arbitrary fluorescence units

AAPH: $\quad 2,2^{\prime}$-Azobis(2-amidinopropane) dihydrochloride

ARDS: $\quad$ Adult respiratory distress syndrome

BJe: Bergamot juice extract

CLSM: Confocal laser scanning microscopy

COPD: Chronic obstructive pulmonary disease

DCF-DA: 2-7-Dichlorofluorescein diacetate

DPPH: 2,2-Diphenylpicrylhydrazyl

DPPP: Diphenyl-1-pyrenylphosphine

$\Delta \psi_{\mathrm{m}}: \quad$ Transmembrane mitochondrial potential

FACS: $\quad$ Fluorescence-activated cell sorting

FBS: $\quad$ Foetal bovine serum

FFBJ: $\quad$ Flavonoid fraction of bergamot juice

FFOJ: Flavonoid fraction of orange juice

GAE: Gallic acid equivalents

8-OH-dG: 8-Hydroxy-2'-deoxyguanosine

ORAC: Oxygen radical scavenging capacity

ROS: $\quad$ Reactive oxygen species

TE: $\quad$ Trolox equivalents. 


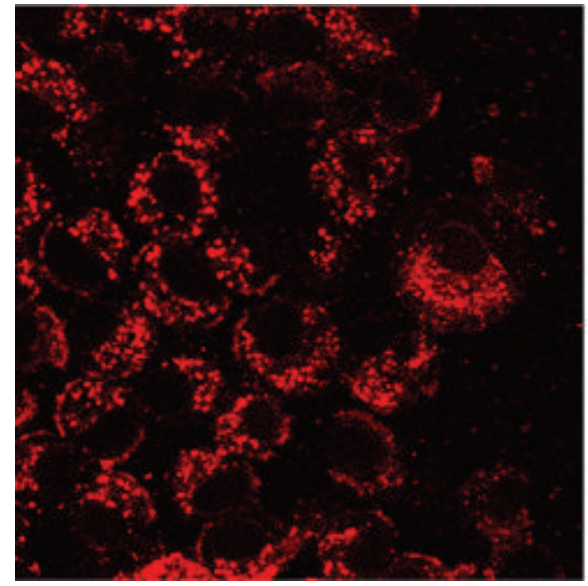

Control

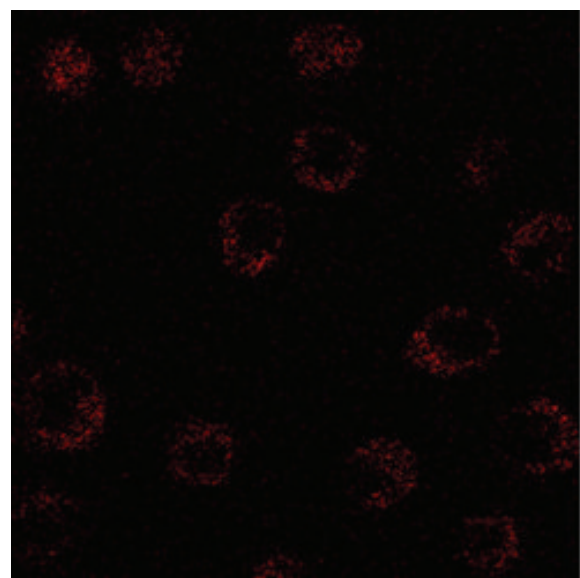

$\mathrm{H}_{2} \mathrm{O}_{2}+\mathrm{FFBJ} 25 \mu \mathrm{g} / \mathrm{mL}$

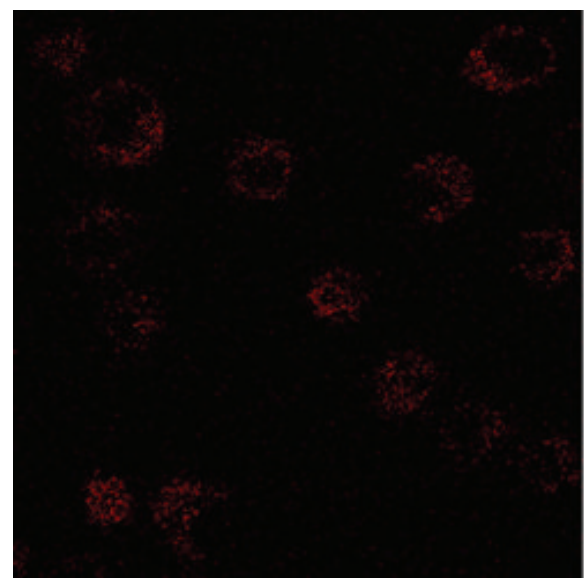

$\mathrm{H}_{2} \mathrm{O}_{2}+\mathrm{FFOJ} 25 \mu \mathrm{g} / \mathrm{mL}$

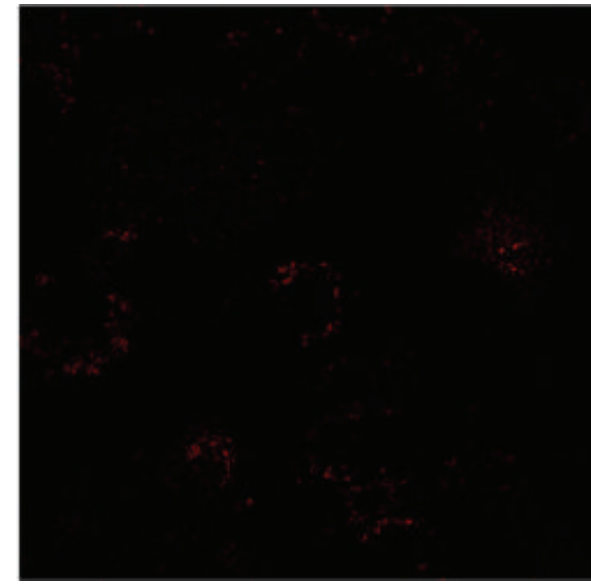

$\mathrm{H}_{2} \mathrm{O}_{2}$

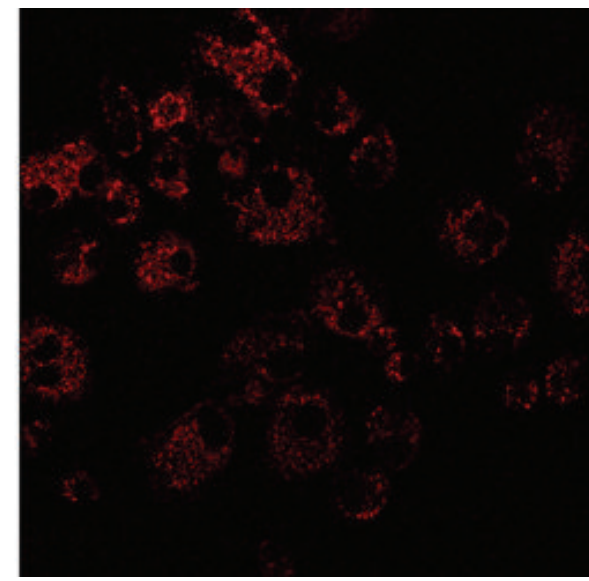

$\mathrm{H}_{2} \mathrm{O}_{2}+\mathrm{FFBJ} 50 \mu \mathrm{g} / \mathrm{mL}$

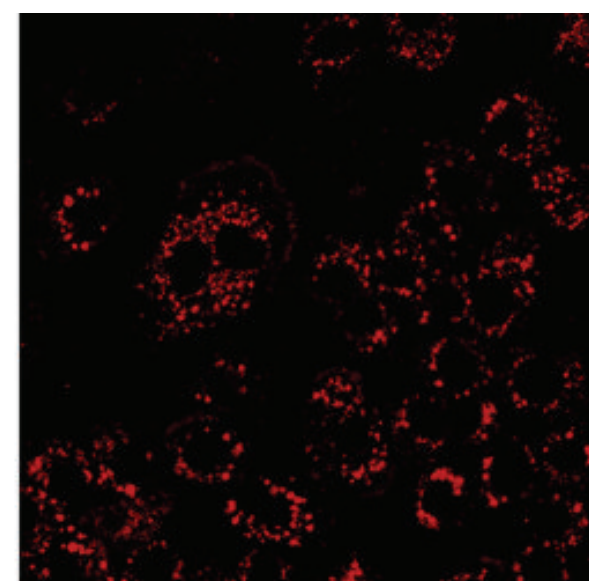

$\mathrm{H}_{2} \mathrm{O}_{2}+\mathrm{FFOJ} 50 \mu \mathrm{g} / \mathrm{mL}$

FIGURE 8: CLSM analysis of mitochondrial membrane potential. A549 cells were grown on cell slides and after treatment with FFBJ or FFOJ were incubated with $\mathrm{H}_{2} \mathrm{O}_{2}$. Mitochondrial membrane potential was detected by R123 staining. Red fluorescence indicates functional mitochondria. Images captured at 400x magnification are shown as representative from three independent experiments. 


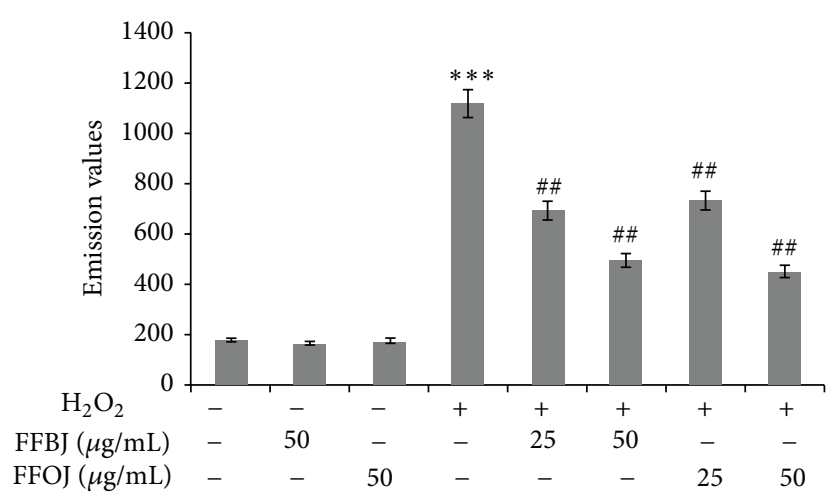

(a)

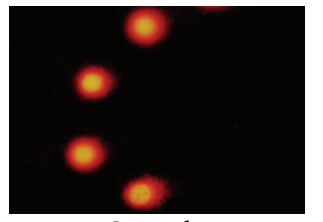

Control

TDNA $6.41 \pm 0.31$

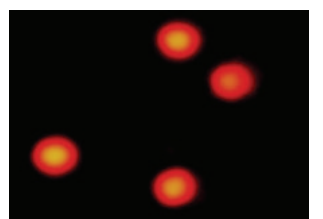

FFBJ $50 \mu \mathrm{g} / \mathrm{mL}$

TDNA $5.05 \pm 0.28$

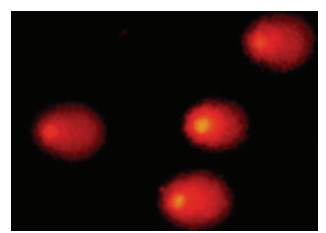

$\mathrm{H}_{2} \mathrm{O}_{2}+\mathrm{FFBJ} 25 \mu \mathrm{g} / \mathrm{mL}$

TDNA $41.70 \pm 2.72$

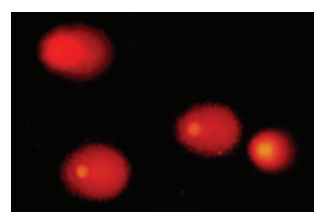

$\mathrm{H}_{2} \mathrm{O}_{2}+$ FFOJ $25 \mu \mathrm{g} / \mathrm{mL}$ TDNA $44.83 \pm 2.11$

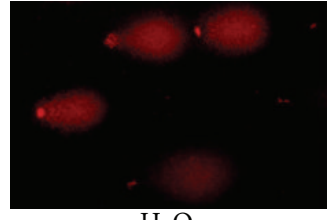

$\mathrm{H}_{2} \mathrm{O}_{2}$

TDNA $82.50 \pm 2.69$

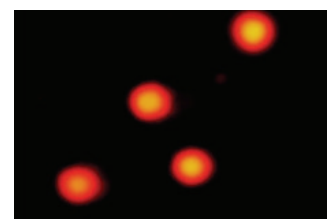

FFOJ $50 \mu \mathrm{g} / \mathrm{mL}$

TDNA $5.87 \pm 0.33$

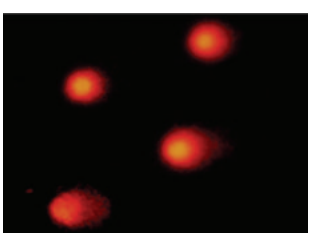

$\mathrm{H}_{2} \mathrm{O}_{2}+\mathrm{FFBJ} 50 \mu \mathrm{g} / \mathrm{mL}$

TDNA $29.21 \pm 1.80$

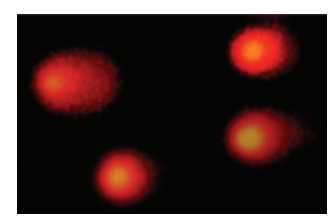

$\mathrm{H}_{2} \mathrm{O}_{2}+\mathrm{FFOJ} 50 \mu \mathrm{g} / \mathrm{mL}$

TDNA $27.25 \pm 0.83$ (b)

FIGURE 9: Protective effects of FFBJ and FFOJ on DNA damage induced by $\mathrm{H}_{2} \mathrm{O}_{2}$. (a) Levels of 8-oxo-dG are measured as emission signals of fluorochrome FITC-labeled avidin collected in the FL1 channel. The graph reports the mean of fluorescence expressed in arbitrary fluorescence units (AFU) of three independent experiments. ${ }^{* * *} P<0.001$ versus control cultures and ${ }^{\# \#} P<0.01$ versus $\mathrm{H}_{2} \mathrm{O}_{2}$-treated cells. (b) Images of comet assay captured by fluorescence microscopy at a magnification of $400 \mathrm{x}$. A representative experiment that was replicated three times with similar results is shown. Percentages of tail DNA (TDNA) are indicated.

\section{Conflict of Interests}

The authors declare that there is no conflict of interests. Agrumaria Corleone had no role in study design, data collection and analysis, decision to publish, or preparation of the paper.

\section{Authors' Contribution}

Nadia Ferlazzo and Giuseppa Visalli performed experiments and assisted in the drafting pf the paper; Antonella Smeriglio, Santa Cirmi, and Giovanni Enrico Lombardo performed experiments; Pietro Campiglia executed UHPLCl analysis; Angela Di Pietro and Michele Navarra designed experiments and drafted the paper. Nadia Ferlazzo and Giuseppa Visalli contributed equally to this work and share the first authorship.

\section{Acknowledgments}

This research was supported by grants from Sicily Region (PO FESR Sicilia 2007/2013, CUP G73F11000050004, Project "MEPRA," no. 133 of Linea d'Intervento 4.1.1.1) and from Calabria Region (PSR Calabria 2007/2013 misura 124, Project “ABSIB").

\section{References}

[1] L. Zuo, N. P. Otenbaker, B. A. Rose, and K. S. Salisbury, "Molecular mechanisms of reactive oxygen species-related pulmonary inflammation and asthma," Molecular Immunology, vol. 56, no. 1-2, pp. 57-63, 2013.

[2] W. MacNee, "Oxidative stress and lung inflammation in airways disease," European Journal of Pharmacology, vol. 429, no. 1-3, pp. 195-207, 2001.

[3] J. Bousquet and N. G. Khaltaev, Global Surveillance, Prevention and Control of Chronic Respiratory Diseases: A Comprehensive Approach, World Health Organization, Geneva, Switzerland, 2007.

[4] G. Pelaia, G. Cuda, A. Vatrella et al., "Effects of hydrogen peroxide on MAPK activation, IL-8 production and cell viability in primary cultures of human bronchial epithelial cells," Journal of Cellular Biochemistry, vol. 93, no. 1, pp. 142-152, 2004.

[5] R. Maselli, R. D. Grembiale, G. Pelaia, and G. Cuda, "Oxidative stress and lung diseases," Monaldi Archives for Chest Disease, vol. 57, no. 3-4, pp. 180-181, 2002.

[6] C. A. Rice-Evans, N. J. Miller, and G. Paganga, "Antioxidant properties of phenolic compounds," Trends in Plant Science, vol. 2, no. 4, pp. 152-159, 1997.

[7] J. A. Ross and C. M. Kasum, "Dietary flavonoids: bioavailability, metabolic effects, and safety," Annual Review of Nutrition, vol. 22, pp. 19-34, 2002.

[8] V. Di Matteo and E. Esposito, "Biochemical and therapeutic effects of antioxidants in the treatment of Alzheimer's disease, Parkinson's disease, and amyotrophic lateral sclerosis," Current Drug Target-CNS \& Neurological Disorders, vol. 2, no. 2, pp. 95-107, 2003.

[9] L. H. Yao, Y. M. Jiang, J. Shi et al., "Flavonoids in food and their health benefits," Plant Foods for Human Nutrition, vol. 59, no. 3, pp. 113-122, 2004. 
[10] S. Kumar and A. K. Pandey, "Chemistry and biological activities of flavonoids: an overview," The Scientific World Journal, vol. 2013, Article ID 162750, 16 pages, 2013.

[11] P. Mladěnka, K. Macáková, T. Filipský et al., "In vitro analysis of iron chelating activity of flavonoids," Journal of Inorganic Biochemistry, vol. 105, no. 5, pp. 693-701, 2011.

[12] C. Chen and A. N. Kong, "Dietary cancer-chemopreventive compounds: from signaling and gene expression to pharmacological effects," Trends in Pharmacological Sciences, vol. 26, no. 6, pp. 318-326, 2005.

[13] R. Masella, R. Di Benedetto, R. Varì, C. Filesi, and C. Giovannini, "Novel mechanisms of natural antioxidant compounds in biological systems: involvement of glutathione and glutathionerelated enzymes," Journal of Nutritional Biochemistry, vol. 16, no. 10, pp. 577-586, 2005.

[14] H. Kumar, I. S. Kim, S. V. More, B. W. Kim, and D. K. Choi, "Natural product-derived pharmacological modulators of Nrf2/ARE pathway for chronic diseases," Natural Product Reports, vol. 31, no. 1, pp. 109-139, 2014.

[15] O. Benavente-García and J. Castillo, "Update on uses and properties of citrus flavonoids: new findings in anticancer, cardiovascular, and anti-inflammatory activity," Journal of Agricultural and Food Chemistry, vol. 56, no. 15, pp. 6185-6205, 2008.

[16] G. Grosso, F. Galvano, A. Mistretta et al., "Red orange: experimental models and epidemiological evidence of its benefits on human health," Oxidative Medicine and Cellular Longevity, vol. 2013, Article ID 157240, 11 pages, 2013.

[17] M. Navarra, C. Mannucci, M. Delbò, and G. Calapai, “Citrus bergamia essential oil: from basic research to clinical application," Frontiers in Pharmacology, vol. 6, article 36, 2015.

[18] A. Marino, I. Paterniti, M. Cordaro et al., "Role of natural antioxidants and potential use of bergamot in treating rheumatoid arthritis," PharmaNutrition, vol. 3, no. 2, pp. 53-59, 2015.

[19] S. Delle Monache, P. Sanità, E. Trapasso et al., "Mechanisms underlying the anti-tumoral effects of Citrus bergamia juice," PLoS ONE, vol. 8, no. 4, Article ID e61484, 2013.

[20] M. Navarra, M. R. Ursino, N. Ferlazzo, M. Russo, U. Schumacher, and U. Valentiner, "Effect of Citrus bergamia juice on human neuroblastoma cells in vitro and in metastatic xenograft models," Fitoterapia, vol. 95, pp. 83-92, 2014.

[21] G. Visalli, N. Ferlazzo, S. Cirmi et al., "Bergamot juice extract inhibits proliferation by inducing apoptosis in human colon cancer cells," Anti-Cancer Agents in Medicinal Chemistry, vol. 14, no. 10, pp. 1402-1413, 2014.

[22] R. Risitano, M. Currò, S. Cirmi et al., "Flavonoid fraction of Bergamot juice reduces LPS-induced inflammatory response through SIRT1-mediated NF-kappaB inhibition in THP-1 monocytes," PLoS ONE, vol. 9, no. 9, Article ID e107431, 2014.

[23] D. Impellizzeri, G. Bruschetta, R. Di Paola et al., "The antiinflammatory and antioxidant effects of bergamot juice extract (BJe) in an experimental model of inflammatory bowel disease," Clinical Nutrition, 2014.

[24] H. A. Smit, L. Grievink, and C. Tabak, "Dietary influences on chronic obstructive lung disease and asthma: a review of the epidemiological evidence," Proceedings of the Nutrition Society, vol. 58, no. 2, pp. 309-319, 1999.

[25] S. Biswas, J. W. Hwang, P. A. Kirkham, and I. Rahman, "Pharmacological and dietary antioxidant therapies for chronic obstructive pulmonary disease," Current Medicinal Chemistry, vol. 20, no. 12, pp. 1496-1530, 2013.
[26] C. Tabak, I. C. W. Arts, H. A. Smit, D. Heederik, and D. Kromhout, "Chronic obstructive pulmonary disease and intake of catechins, flavonols, and flavones: the morgen study," American Journal of Respiratory and Critical Care Medicine, vol. 164, no. 1, pp. 61-64, 2001.

[27] R. K. Woods, E. H. Walters, J. M. Raven et al., "Food and nutrient intakes and asthma risk in young adults," American Journal of Clinical Nutrition, vol. 78, no. 3, pp. 414-421, 2003.

[28] R. Barros, A. Moreira, J. Fonseca et al., "Adherence to the Mediterranean diet and fresh fruit intake are associated with improved asthma control," Allergy, vol. 63, no. 7, pp. 917-923, 2008.

[29] E. Keranis, D. Makris, P. Rodopoulou et al., "Impact of dietary shift to higher-antioxidant foods in COPD: a randomised trial," European Respiratory Journal, vol. 36, no. 4, pp. 774-780, 2010.

[30] M. Homma, M. Minami, C. Taniguchi et al., "Inhibitory effects of lignans and flavonoids in Saiboku-To, a herbal medicine for bronchial asthma, on the release of leukotrienes from human polymorphonuclear leukocytes," Planta Medica, vol. 66, no. 1, pp. 88-91, 2000.

[31] A. Tomaino, M. Martorana, T. Arcoraci, D. Monteleone, C. Giovinazzo, and A. Saija, "Antioxidant activity and phenolic profile of pistachio (Pistacia vera L., variety Bronte) seeds and skins," Biochimie, vol. 92, no. 9, pp. 1115-1122, 2010.

[32] A. Dávalos, C. Gómez-Cordovés, and B. Bartolomé, "Extending applicability of the oxygen radical absorbance capacity (ORACfluorescein) assay," Journal of Agricultural and Food Chemistry, vol. 52, no. 1, pp. 48-54, 2004.

[33] M. Martorana, T. Arcoraci, L. Rizza et al., "In vitro antioxidant and in vivo photoprotective effect of pistachio (Pistacia vera L., variety Bronte) seed and skin extracts," Fitoterapia, vol. 85, no. 1, pp. 41-48, 2013.

[34] A. Di Pietro, G. Visalli, F. Munaò et al., "Oxidative damage in human epithelial alveolar cells exposed in vitro to oil fly ash transition metals," International Journal of Hygiene and Environmental Health, vol. 212, no. 2, pp. 196-208, 2009.

[35] A. Di Pietro, B. Baluce, G. Visalli, S. la Maestra, R. Micale, and A. Izzotti, "Ex vivo study for the assessment of behavioral factor and gene polymorphisms in individual susceptibility to oxidative DNA damage metals-induced," International Journal of Hygiene and Environmental Health, vol. 214, no. 3, pp. 210218, 2011.

[36] E. Ferro, G. Visalli, R. Civa et al., "Oxidative damage and genotoxicity biomarkers in transfused and untransfused thalassemic subjects," Free Radical Biology and Medicine, vol. 53, no. 10, pp. 1829-1837, 2012.

[37] D. Mangal, D. Vudathala, J.-H. Park, H. L. Seon, T. M. Penning, and I. A. Blair, "Analysis of 7,8-dihydro-8-oxo-2' deoxyguanosine in cellular DNA during oxidative stress," Chemical Research in Toxicology, vol. 22, no. 5, pp. 788-797, 2009.

[38] I. Picerno, C. Chirico, S. Condello et al., "Homocysteine induces DNA damage and alterations in proliferative capacity of Tlymphocytes: a model for immunosenescence?" Biogerontology, vol. 8, no. 2, pp. 111-119, 2007.

[39] J.-Y. Hsu, J.-J. Chu, M.-C. Chou, and Y.-W. Chen, "Dioscorin pre-treatment protects A549 human airway epithelial cells from hydrogen peroxide-induced oxidative stress," Inflammation, vol. 36, no. 5, pp. 1013-1019, 2013.

[40] P. F. Mercer, R. H. Johns, C. J. Scotton et al., "Pulmonary epithelium is a prominent source of proteinase-activated receptor1-inducible CCL2 in pulmonary fibrosis," American Journal of 
Respiratory and Critical Care Medicine, vol. 179, no. 5, pp. 414425, 2009.

[41] F. Antunes and E. Cadenas, "Cellular titration of apoptosis with steady state concentrations of $\mathrm{H}_{2} \mathrm{O}_{2}$ : submicromolar levels of $\mathrm{H}_{2} \mathrm{O}_{2}$ induce apoptosis through fenton chemistry independent of the cellular thiol state," Free Radical Biology and Medicine, vol. 30, no. 9, pp. 1008-1018, 2001.

[42] J. R. Stone and S. Yang, "Hydrogen peroxide: a signaling messenger," Antioxidants \& Redox Signaling, vol. 8, no. 3-4, pp. 243-270, 2006.

[43] D. J. Huang, B. X. Ou, and R. L. Prior, "The chemistry behind antioxidant capacity assays," Journal of Agricultural and Food Chemistry, vol. 53, no. 6, pp. 1841-1856, 2005.

[44] C.-D. Zheng, G. Li, H.-Q. Li, X.-J. Xu, J.-M. Gao, and A.L. Zhang, "DPPH-scavenging activities and structure-activity relationships of phenolic compounds," Natural Product Communications, vol. 5, no. 11, pp. 1759-1765, 2010.

[45] D. Di Majo, M. Giammanco, M. La Guardia, E. Tripoli, S. Giammanco, and E. Finotti, "Flavanones in Citrus fruit: structure-antioxidant activity relationships," Food Research International, vol. 38, no. 10, pp. 1161-1166, 2005.

[46] K. E. Heim, A. R. Tagliaferro, and D. J. Bobilya, "Flavonoid antioxidants: chemistry, metabolism and structure-activity relationships," The Journal of Nutritional Biochemistry, vol. 13, no. 10, pp. 572-584, 2002.

[47] J. H. G. Lago, A. C. Toledo-Arruda, M. Mernak et al., "StructureActivity association of flavonoids in lung diseases," Molecules, vol. 19, no. 3, pp. 3570-3595, 2014.

[48] Y.-H. Chen, Z.-S. Yang, C.-C. Wen et al., "Evaluation of the structure-activity relationship of flavonoids as antioxidants and toxicants of zebrafish larvae," Food Chemistry, vol. 134, no. 2, pp. 717-724, 2012.

[49] D. Procházková, I. Boušová, and N. Wilhelmová, “Antioxidant and prooxidant properties of flavonoids," Fitoterapia, vol. 82, no. 4, pp. 513-523, 2011.

[50] C. López-Alarcón and A. Denicola, "Evaluating the antioxidant capacity of natural products: a review on chemical and cellularbased assays," Analytica Chimica Acta, vol. 763, pp. 1-10, 2013.

[51] K. Becker, S. Schroecksnadel, J. Gostner et al., "Comparison of in vitro tests for antioxidant and immunomodulatory capacities of compounds," Phytomedicine, vol. 21, no. 2, pp. 164-171, 2014.

[52] W. Song, C. M. Derito, M. K. Liu, X. He, M. Dong, and R. H. Liu, "Cellular antioxidant activity of common vegetables," Journal of Agricultural and Food Chemistry, vol. 58, no. 11, pp. 6621-6629, 2010.

[53] K. A. Foster, C. G. Oster, M. M. Mayer, M. L. Avery, and K. L. Audus, "Characterization of the A549 cell line as a type II pulmonary epithelial cell model for drug metabolism," Experimental Cell Research, vol. 243, no. 2, pp. 359-366, 1998.

[54] P. Paredi, S. A. Kharitonov, D. Leak, S. Ward, D. Cramer, and P. J. Barnes, "Exhaled ethane, a marker of lipid peroxidation, is elevated chronic obstructive pulmonary disease," American Journal of Respiratory and Critical Care Medicine, vol. 162, no. 2, pp. 369-373, 2000.

[55] I. Rahman, "Oxidative stress in pathogenesis of chronic obstructive pulmonary disease: cellular and molecular mechanisms," Cell Biochemistry and Biophysics, vol. 43, no. 1, pp. 167188, 2005.

[56] J. Nair, S. De Flora, A. Izzotti, and H. Bartsch, "Lipid peroxidation-derived etheno-DNA adducts in human atherosclerotic lesions," Mutation Research-Fundamental and Molecular Mechanisms of Mutagenesis, vol. 621, no. 1-2, pp. 95-105, 2007.
[57] I. K. Demedts, T. Demoor, K. R. Bracke, G. F. Joos, and G. G. Brusselle, "Role of apoptosis in the pathogenesis of COPD and pulmonary emphysema," Respiratory Research, vol. 7, article 53, 2006.

[58] J. Lee, S. Giordano, and J. Zhang, "Autophagy, mitochondria and oxidative stress: cross-talk and redox signalling," Biochemical Journal, vol. 441, no. 2, pp. 523-540, 2012. 


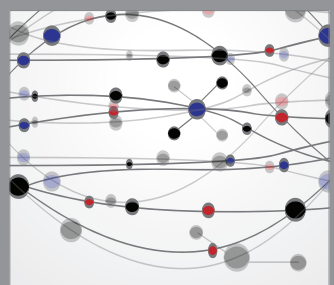

The Scientific World Journal
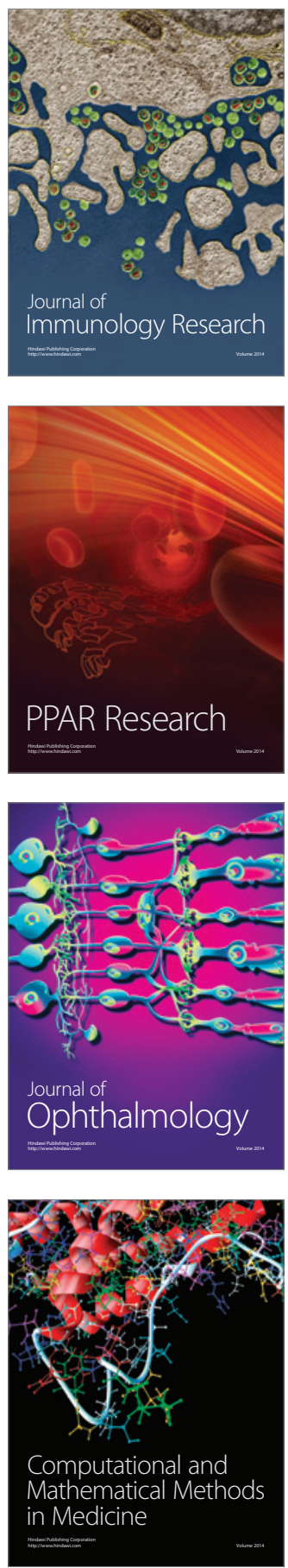

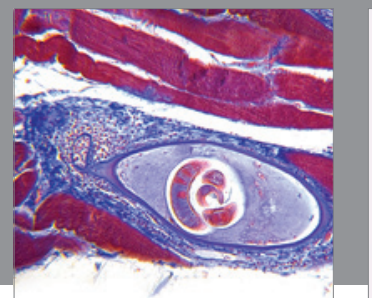

Gastroenterology

Research and Practice
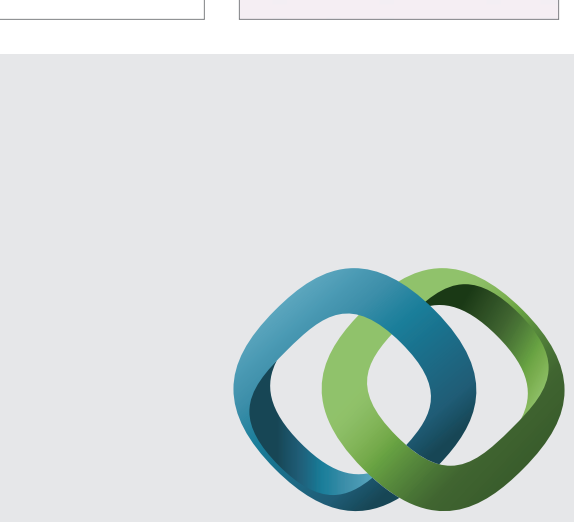

\section{Hindawi}

Submit your manuscripts at

http://www.hindawi.com
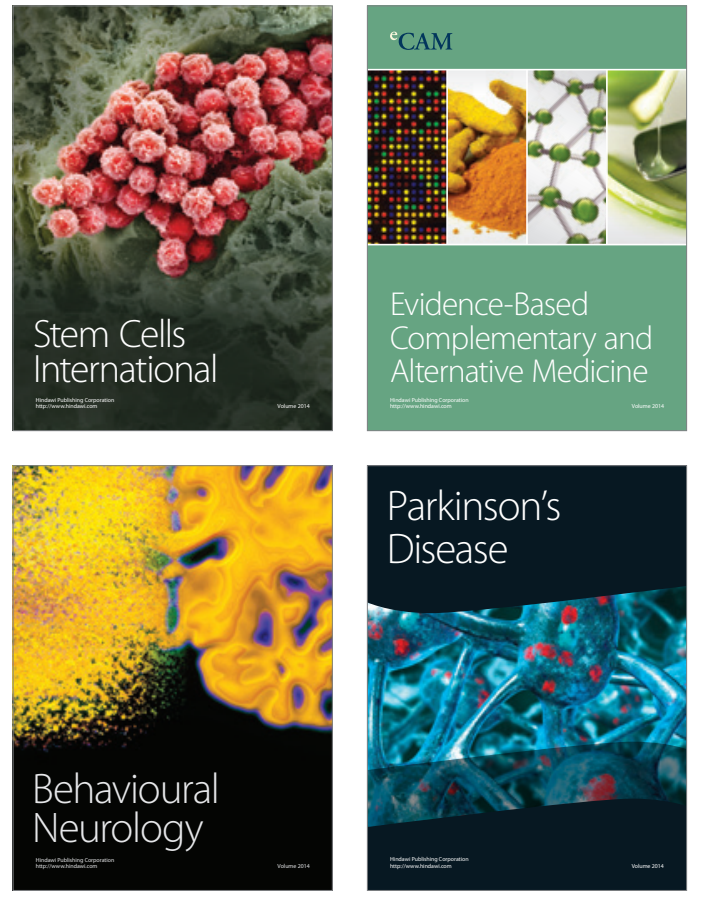
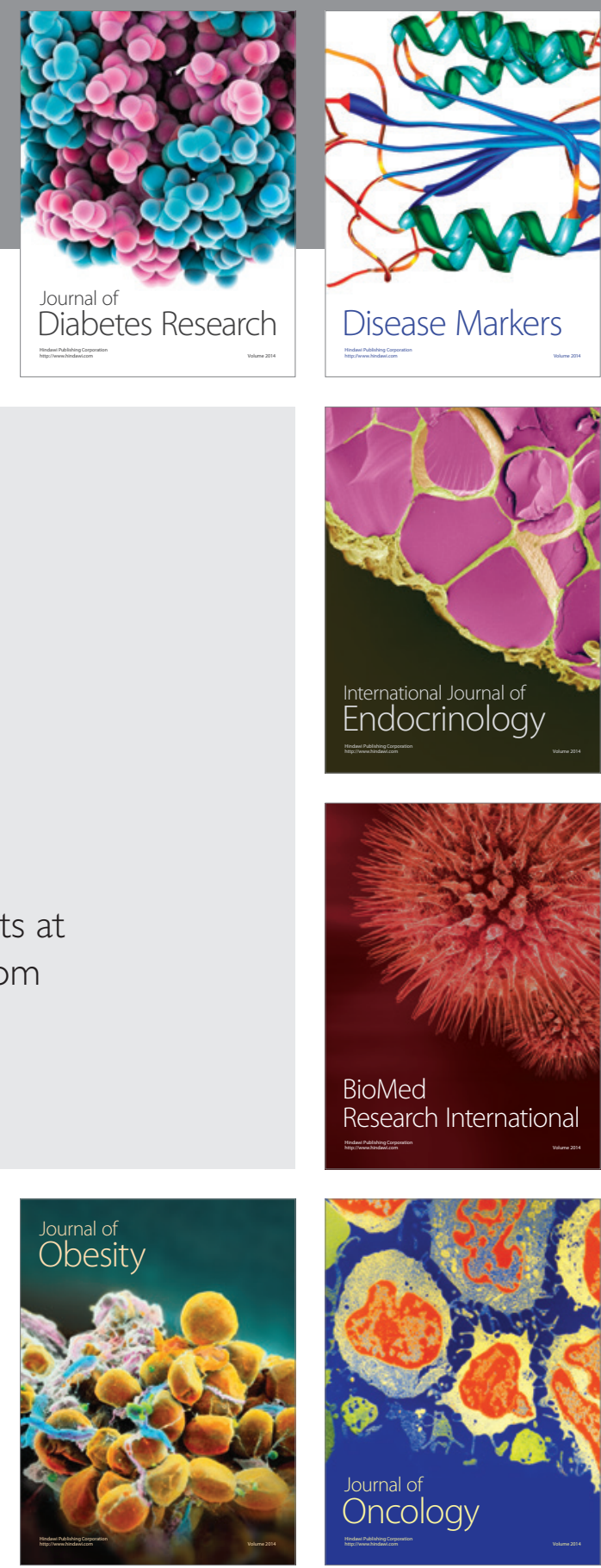

Disease Markers
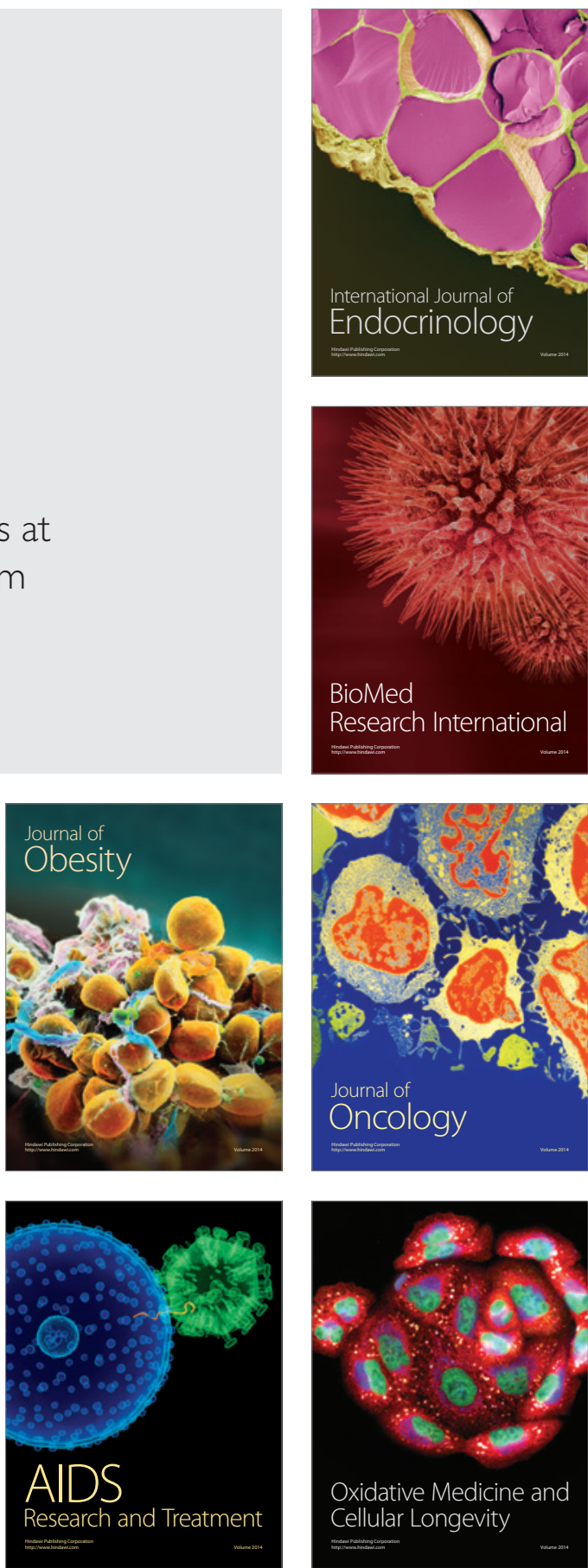